\title{
A geometria plana no ensino fundamental: estudo prático sobre o teodolito
}

José Alves de Amorim 
SERVIÇO DE PÓS-GRADUAÇÃO DO ICMC-USP

Data de Depósito:

Assinatura:

\title{
José Alves de Amorim
}

\section{A geometria plana no ensino fundamental: estudo prático sobre o teodolito}

\author{
Dissertação apresentada ao Instituto de Ciências \\ Matemáticas e de Computação - ICMC-USP, como \\ parte dos requisitos para obtenção do título de \\ Mestre em Ciências - Programa de Mestrado \\ Profissional em Matemática. VERSÃO REVISADA \\ Área de Concentração: Matemática \\ Orientadora: \\ Profa. Dra. Karla Roberta Pereira Sampaio Lima
}

USP - São Carlos

Agosto de 2016 
Ficha catalográfica elaborada pela Biblioteca Prof. Achille Bassi e Seção Técnica de Informática, ICMC/USP, com os dados fornecidos pelo(a) autor(a)

A524g A geometria plana no ensino fundamental: estudo prático sobre o Teodolito / José Alves de Amorim; orientador Karla Roberta Pereira Sampaio Lima. -Săo Carlos, 2016.

$69 \mathrm{p}$.

Dissertação (Mestrado - Programa de Pós-Graduação em Mestrado Profissional em Matemática em Rede Nacional) -- Instituto de Ciências Matemáticas e de Computação, Universidade de São Paulo, 2016.

1. Geometria. 2. Teodolito. 3. Ângulo. 4. Matemática. 5. Atividades Experimentais. I. Lima, Karla Roberta Pereira Sampaio, orient. II. Título. 


\section{José Alves de Amorim}

\section{The plane geometry in elementary school: pratical study of the theodolite}

Master dissertation submitted to the Instituto de Ciências Matemáticas e de Computação - ICMCUSP, in partial fulfillment of the requirements for the degree of Mathematics Professional Master's Program. FINAL VERSION

Concentration Area: Mathematics

Advisor:

Profa. Dra. Karla Roberta Pereira Sampaio Lima

USP - São Carlos

August 2016 
À minha querida esposa Daniela, que sempre está ao meu lado demonstrando seu amor e carinho, me motivando e dando forças nos momentos mais difíceis; e aos meus filhos Bruno e Ana por serem a inspiração da minha vida. 


\section{AGRADECIMENTOS}

A Deus pelo dom da vida.

Aos meus pais Rosilda e José (in memoriam), responsáveis pelo que sou hoje, exemplos de honestidade e determinação, qualidades fundamentais para que eu conseguisse alcançar mais este objetivo.

À professora Dra. Karla Lima pela orientação e disposição para ajudar.

Aos professores da Universidade de São Paulo, que sempre mostraram que este caminho é difícil, porém possível, compartilhando seu conhecimento não apenas dentro, mas também fora da sala de aula.

A todos os professores que passaram pela minha vida acadêmica, pois cada um de sua maneira deu suporte para que este trabalho se concretizasse.

Aos meus colegas de mestrado que tornaram as situações mais difíceis em momentos descontraídos e de grande enriquecimento.

Aos meus amigos de todos os momentos que sempre incentivaram e criticaram quando necessário.

À EMEF Geraldo Sesso Júnior pela infraestrutura e por ceder materiais necessários para realização do projeto, assim como a equipe gestora e demais colegas de trabalho que auxiliaram sempre que necessário.

Aos meus alunos, em especial os $8^{\text {os }}$ anos de 2014, que acreditaram na realização da atividade, tentando concluí-la da melhor forma possível.

À SBM pela criação do PROFMAT, possibilitando a mim e a tantos outros professores de todo país conhecimento de alta qualidade.

À CAPES pela bolsa de estudo concedida e pela Universidade de São Paulo pela oportunidade de participar no programa. 
"Não se deve ir atrás de objetivos fáceis. É preciso buscar o que se pode ser alcançado por meio dos maiores esforços". 


\section{RESUMO}

\section{AMORIM, J. A. A geometria plana no ensino fundamental: estudo prático sobre}

o teodolito. 2016.

69f. Dissertação (Mestrado) - Instituto de Ciências Matemáticas e de Computação, Universidade de São Paulo, São Carlos, 2016.

Este trabalho teve como finalidade o estudo prático de construção de figuras geométricas utilizando instrumentos disponíveis na própria escola. A situação problema apresentada buscou verificar como pode ser possível determinar a medida de regiões inacessíveis através de cálculos e relações geométricas. Para alcançar o objetivo proposto, ou seja, a utilização prática deste instrumento de medida foi realizada a construção de um Teodolito "caseiro", com materiais de baixo custo e que estavam à disposição na própria escola. Por fim, as medidas e os cálculos realizados pelos alunos foram discutidos em sala de aula, analisando possíveis dificuldades e conhecimento adquiridos durante $o$ processo de ensinoaprendizagem.

Palavras-chave: Geometria; Teodolito; Ângulo; Matemática; Atividades Experimentais. 


\begin{abstract}
AMORIM, J. A. The plane geometry in elementary education: practical study of the theodolite. 2016.

69f. Dissertação (Mestrado) - Instituto de Ciências Matemáticas e de Computação, Universidade de São Paulo, São Carlos, 2016.

This work aimed to study the practical construction of geometric figures using tools available at the school. The problem situation presented aims to evaluate how it can be possible to determine the extent of inaccessible areas by calculation and geometric relationships. To achieve the proposed objective, the practical use of this measuring instrument, building a Theodolite "homemade" was held, with low-cost materials that were available at the school. Finally, the measurements and calculations performed by the students were discussed in class, analyzing possible difficulties and knowledge acquired during the teaching-learning process.
\end{abstract}

Keywords: Geometry; Theodolite; Angle; Mathematics; Experimental Activities. 


\section{LISTA DE ILUSTRAÇÕES}

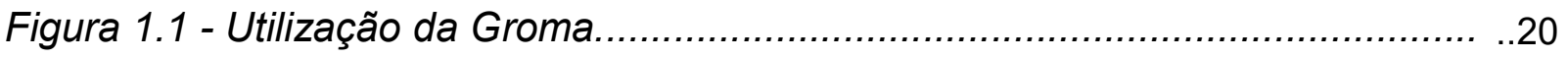

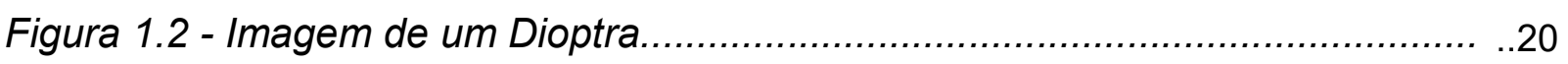

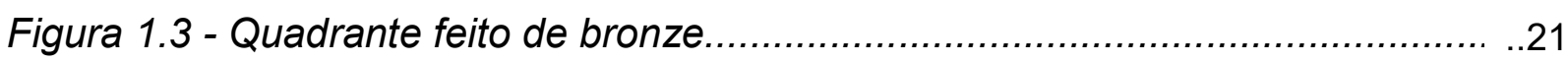

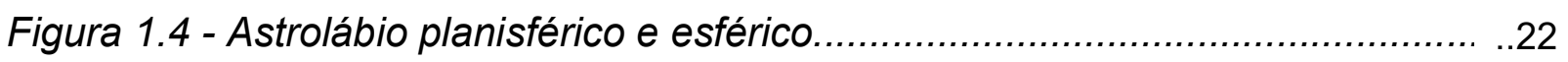

Figura 1.5 - Teodolito do século XIX exposto no acervo Museu de Astronomia e

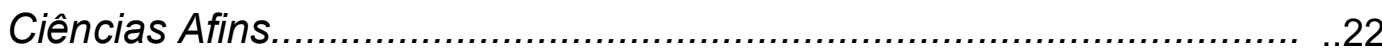

Figura 1.6 - Teodolito mecânico e eletrônico com visor de ângulos com display..... ..23

Figura 1.7 - Esquema do movimento circular das lentes do Teodolito......................24

Figura 1.8 - Determinação do ângulo Azimute................................................ .24

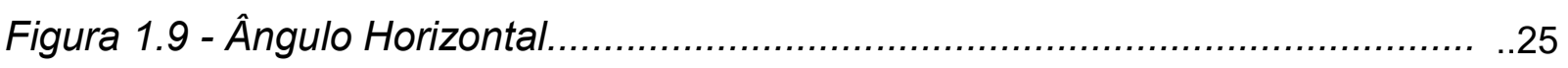

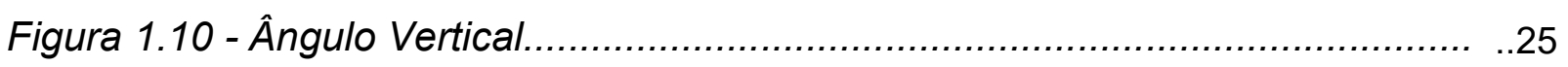

Figura 1.11 - Distância horizontal, vertical e inclinada............................................26

Figura 1.12 - Desenho de um triângulo imaginário formado a partir de pontos nas

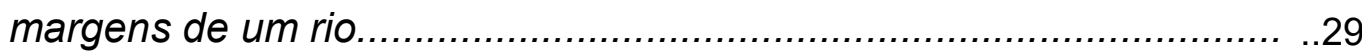

Figura 1.13 - Desenho de triângulos para calcular a altura de uma montanha....... ...31

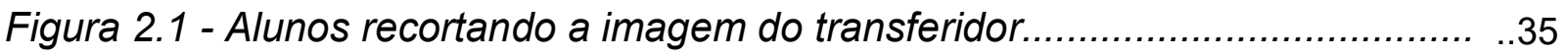

Figura 2.2 - Imagens resultantes da $1^{a}$ etapa do roteiro de construção do

Teodolito.

Figura 2.3 - Alunos colando a imagem do transferidor no papel cartão retangular.. ..36

Figura 2.4 - Alunos utilizando cola quente para colar a tampa do copo

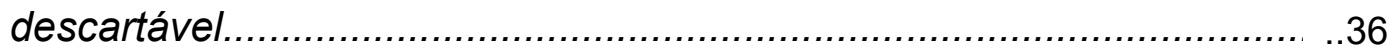

Figura 2.5 - Fixação do pedaço de arame e do canudo no Teodolito...................... ..37

Figura 2.6 - Resultado final da construção do Teodolito..........................................

Figura 2.7 - As reta r e s representam as leituras no Teodolito e o ângulo $\alpha$ apresentado na figura representa a variação angular.

Figura 2.8 - Roteiro de atividade proposta para uso do Teodolito caseiro.

Figura 2.9 - Alunos realizando as medidas no pátio da escola, a ultima imagem é referente ao muro de altura desejada.

Figura 2.10 - Representação dos triângulos que foram usados pelos alunos........... .44

Figura 3.1 - Valores obtidos utilizando os instrumentos de medidas. Aluno A...........48

Figura 3.2 - Valores obtidos utilizando os instrumentos de medidas. Aluno B......... ..49 
Figura 3.3 - Valores obtidos utilizando os instrumentos de medidas. Aluno C . .50

Figura 3.4 - Cálculos desenvolvidos para obter a altura do muro da escola.

Aluno A.

Figura 3.5 - Cálculos desenvolvidos para obter a altura do muro da escola.

Aluno $B$.

Figura 3.6 - Cálculos desenvolvidos para obter a altura do muro da escola.

Aluno C.

Figura 3.7 - Histograma representando os valores calculados pelos alunos do $8^{\circ} A$

Figura 3.8 - Histograma representando os valores calculados pelos alunos do $8^{\circ} \mathrm{B}$

Figura 3.9 - Histograma representando os valores calculados pelos alunos do $8^{\circ} \mathrm{C}$ . .57

Figura 3.10 - Histograma representando os valores calculados pelos alunos do $8^{\circ} D$ .58

Figura 3.11 - Histograma representando os valores calculados de todos alunos. .60 


\section{LISTA DE TABELAS}

Tabela 3.1 - Valores da altura obtidos pelos alunos, agrupados por turma...............55

Tabela 3.2 - Dados calculados para facilitar a distribuição de frequência. $\quad .55$

Tabela 3.3 - Valores agrupados por turma, expostos em distribuição de frequência..56

Tabela 3.4 - Altura média obtida por cada turma...............................................58

Tabela 3.5 - Dados calculados para facilitar a distribuição de frequência, utilizando todos valores agrupados...... 59

Tabela 3.6 - Valores agrupados, expostos em distribuição de frequência.............. .59 


\section{SUMÁRIO}

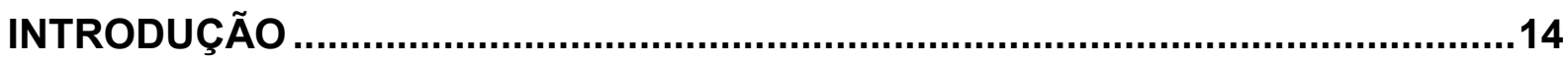

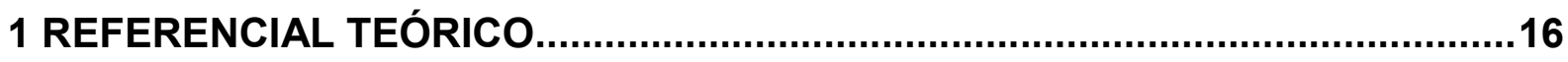

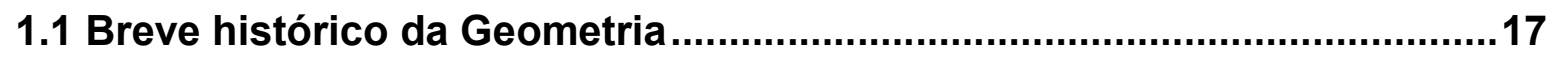

1.2 Dificuldades de Aprendizagem em Geometria ...........................................18

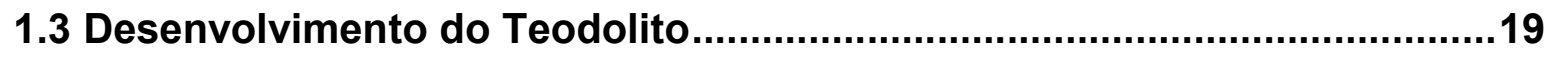

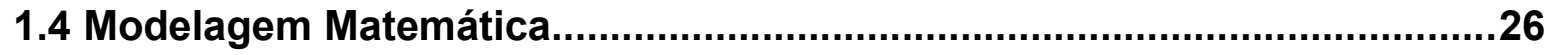

1.5 Aplicações do Teodolito no contexto escolar..........................................29

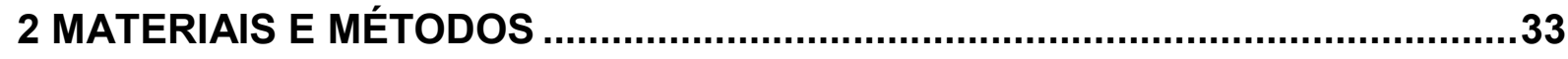

2.1 Construção do Teodolito "caseiro" ..........................................................33

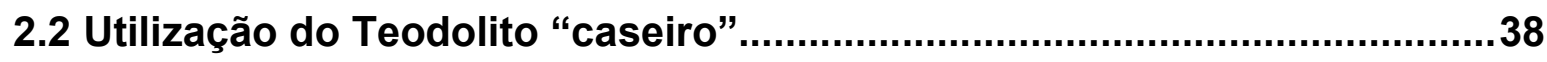

2.2.1 Esclarecimentos da utilização do Teodolito.........................................38

2.2.2 Atividade prática utilizando o Teodolito ...............................................40

2.3 Cálculos utilizados para obtenção da medida da altura do prédio da

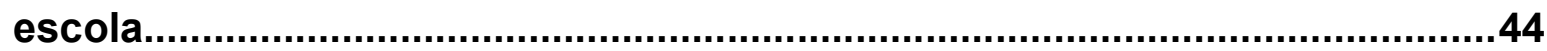

2.4 Cálculos realizados para comparação dos valores calculados com o

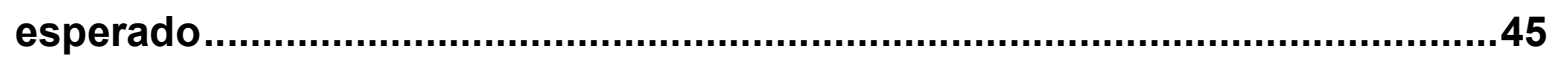

3 RESULTADOS

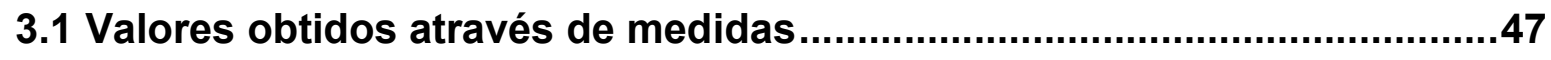

3.2 Valores obtidos através de cálculos .....................................................51

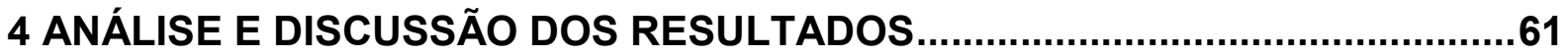

5 CONCLUSÕES

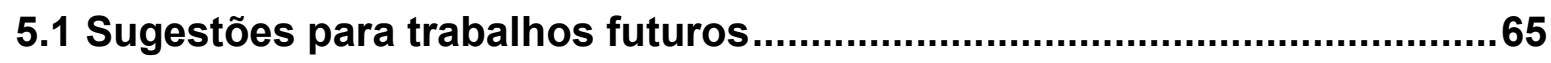

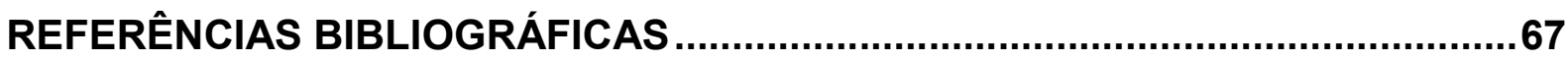




\section{INTRODUÇÃO}

As avaliações externas (Saresp, Prova Brasil, Prova mais educação, ...) que são aplicadas pelos governos municipal, estadual e nacional têm demonstrado que o desempenho dos estudantes do ensino fundamental nas escolas públicas nos últimos anos não vem sendo satisfatório, especialmente no campo das ciências exatas. Os resultados não satisfatórios faz com que muitos educadores sintam-se intrigados sobre quais métodos podem ser mais eficientes ou práticos do ponto de vista de atrelar os conteúdos acadêmicos à necessidade da vida prática e cotidiana. Nesse sentido, é necessário rever alguns conceitos que fazem parte do processo do aprendizado, dentre eles os métodos educativos utilizados.

Dentro desse contexto, verificamos que no cotidiano da sala de aula é recorrente a falta de interesse e o baixo rendimento dos estudantes em Matemática, onde fica quase que impossível identificar se a falta de interesse por parte dos alunos conduz a um baixo rendimento escolar ou se a dificuldade dos alunos na disciplina de Matemática e consequente baixo rendimento escolar induz os alunos ao desinteresse pela disciplina.

Com o intuito de resgatar o interesse dos alunos pela Matemática este trabalho propôs uma pesquisa com atividades diferenciadas para o ensino da geometria, onde os alunos poderiam de forma concreta verificar a utilidade do conteúdo estudado. Como norteador este trabalho seguiu as Orientações Curriculares e Proposição de Expectativas de Aprendizagem para o Ensino Fundamental na disciplina de Matemática, em particular a Geometria. A parte prática foi realizada em uma escola Municipal da Cidade de São Paulo, aplicada em quatro turmas de $8^{\circ}$ ano, no ano letivo de 2014. A realização da atividade com os alunos permitiu verificar se houve aumento no interesse dos mesmos em Matemática e se de alguma forma a nova abordagem metodológica resultou em expectativas de aprendizagem mais satisfatórias. A descrição da pesquisa foi separada em cinco seções, sendo:

- Capítulo 1 - Neste capítulo há uma revisão teórica com os principais autores que discutem a geometria como subárea da Matemática. Nesta seção há 
esclarecimentos sobre "Breve histórico da Geometria"; "Dificuldades de aprendizagem em Geometria"; "Desenvolvimento do Teodolito"; "Modelagem Matemática" e "Aplicações do Teodolito no contexto escolar".

- Capítulo 2 - Materiais e Métodos: Este capítulo explica como foi realizado o trabalho em sala de aula com os alunos, desde a construção do Teodolito até a realização dos cálculos. Esta seção está dividida nos seguintes tópicos: "Construção do Teodolito "caseiro"'; "Utilização do Teodolito "caseiro"', sendo esse dividido em "Esclarecimentos da utilização do Teodolito" e "Atividade prática utilizando o Teodolito"; e "Cálculo para obtenção da medida da altura do prédio da escola".

- Capítulo 3 - Resultados. Nesta seção há os resultados obtidos usando os instrumentos de medidas e cálculos realizados. O capítulo foi separado em dois tópicos: "Valores obtidos através de medidas"; e "Valores obtidos através de cálculos";

- Capítulo 4 - Análise e Discussão dos Resultados. Neste capítulo os valores obtidos são confrontados com os valores esperados, procurando verificar a eficácia do procedimento pratico realizado;

- Capítulo 5 - Conclusões. Neste capítulo, utilizando a análise realizada no capítulo 4, foram expostas as conclusões em relação à coleta de dados, assim como os cálculos realizados posteriormente pelos alunos, explicando a viabilidade do trabalho e suas dificuldades. Ainda há o tópico: "Sugestões para trabalhos futuros", que abrange as sugestões para possíveis projetos futuros. 


\section{REFERENCIAL TEÓRICO}

A Matemática está presente cotidianamente em nossas vidas. Ela assume grande importância sob vários aspectos: no trabalho, em casa, na escola. São tantas as aplicações da Matemática que muitas vezes sequer nos damos conta das infinitas aplicações que podemos dar a ela em nosso cotidiano. Inegavelmente, vivemos ancorados sobre os números, desde o momento em que acordamos até o momento em que vamos dormir. Não é exagero, portanto, dizer que vivemos rodeados de marcações e expressões numéricas.

A Matemática, em si, não é uma ciência nova, mas para muitos é um grande mistério. Seu desenvolvimento está ligado ao raciocínio lógico que debruça-se sobre a necessidade humana de achar respostas, de sanar dúvidas e curiosidades, de descobrir, enfim. Desde sempre o homem vem caminhando em uma busca incansável de obter respostas para os fenômenos e acontecimentos da vida. Isso despertou o interesse pelos cálculos e pelos números, pois o avanço das teorias matemáticas e suas aplicações possibilitaram muitas invenções e descobertas.

$\mathrm{Na}$ escola nem sempre a Matemática é relacionada com a vida prática, mas vemos que no mundo moderno cada vez mais isso se faz urgente e necessário. A relação da Matemática com o cotidiano exige um conhecimento amplo, por isso devemos dar atenção a esse aspecto quando falamos de sua aplicação dentro da escola, nas etapas que envolvem os processos de ensino e aprendizagem como componente curricular.

Se para muitas pessoas ela é uma ciência abstrata ou muito teórica e pouco prática, entendemos que esse paradigma precisa ser quebrado. Então esta pesquisa propõe unir a teoria à prática, ou seja, aquilo que se vê no dia-a-dia como objeto de estudo nos bancos escolares, daí a sugestão de trazer os estudos exatos mais próximos da realidade das pessoas, e não como uma mera abstração de números e fórmulas decoradas.

Por isso, esta pesquisa buscou explorar aspectos práticos da Matemática, a fim de despertar o interesse dos alunos, convidando-os não apenas a realizar exercícios matemáticos, mas de interagir de modo prático na construção de um instrumento que pudesse ser útil e, ao mesmo tempo, de baixo custo. 
A geometria, como subárea da Matemática na grade curricular do ensino fundamental, foi o ponto de partida para esta pesquisa. A proposta inicial foi a construção de um Teodolito "caseiro", onde a principal motivação para os alunos foi a participação em todas as etapas do processo. Após a construção do Teodolito os alunos foram apresentados a uma situação usual do aparelho por eles desenvolvido, colocando em prática na própria escola a teoria demonstrada em sala de aula.

\subsection{Breve histórico da Geometria}

A geometria surgiu como campo do conhecimento ligado às relações espaciais. É difícil precisar a origem da Geometria, pois segundo Carl B. Boyer sua invenção é bastante antiga:

Afirmações sobre a origem da Matemática, seja da aritmética seja da geometria, são necessariamente arriscadas, pois os primórdios de assunto são mais antigos que a arte de escrever. (BOYER, 1974, p. 4).

Heródoto acreditava que a geometria havia se originado no Egito, devido à necessidade prática de fazer novas medidas de terra após cada inundação anual do vale do rio. Aristóteles defendia que a existência no Egito de uma classe sacerdotal com lazeres é que tinha conduzido ao estudo da geometria (BOYER, 1974).

A geometria (do grego "medir a terra") estaria, portanto, ligada a algumas práticas do cotidiano relacionadas ao plantio, construção e movimento dos astros, sendo utilizada para cálculo de áreas, volumes e superfícies.

Desde a antiguidade, de acordo com a necessidade, a geometria passou por inúmeras mudanças. Neste ramo da Matemática podemos citar inúmeros filósofos que contribuíram para o desenvolvimento da geometria, como: Heródoto, Aristóteles, Platão, Pitágoras, Euclides, Eratóstenes, Euler, entre outros. Cada um certamente deixou o seu legado na história da Matemática.

Ainda na antiguidade em paralelo com o desenvolvimento da geometria houve a necessidade da criação de instrumentos utilizados para realizar medições, como, por exemplo, a necessidade de medir o tamanho de uma propriedade. Inicialmente os instrumentos foram criados de forma rudimentar, sem graduação, a fim de atender a necessidade da época. Posteriormente foram desenvolvidos métodos de 
calibração e de graduação e, assim, começaram a existir instrumentos úteis na mensuração de distâncias terrestres, na navegação e na observação de astros, o que auxiliou o desenvolvimento da ciência, em especial a astronomia.

Em tempos mais recentes, os conceitos geométricos valem-se de um alto nível de complexidade, sendo submetidos a métodos de cálculo e álgebra abstrata para fins de composição de suas teorias e modos de aplicação.

\subsection{Dificuldades de Aprendizagem em Geometria}

A Matemática teve início como forma de auxiliar as atividades básicas da civilização e ao longo dos anos passou por diversas modificações e aprimoramentos. Apesar da abrangência do seu campo de pesquisa, a Matemática só foi introduzida como parte do currículo escolar no período da Revolução Industrial, como forma de atender a grande necessidade da época, principalmente no uso de gráficos e sistemas de porcentagem.

Na década de 1950 o movimento de reforma no ensino de Matemática, que visava especialmente na alteração do currículo começou a crescer. As alterações defendiam que a Matemática deveria ser apresentada com maior rigor, enfatizando seus axiomas e demonstrações. Os reformistas não conseguiram aplicar o rigor que eles achavam necessário em alguns fatos geométricos e muitos resolveram diminuir drasticamente o conteúdo referente à geometria nas escolas. Desde então, a geometria nunca mais foi contemplada de forma satisfatória (CHAVES, 2013, p. 20).

No dia a dia é perceptível que muitos estudantes encontram grandes dificuldades quando diz respeito à disciplina Matemática, principalmente na necessidade de buscar as aplicações ao assunto que está sendo apresentado. Especificamente em geometria os livros didáticos cobram muito a questão da abstração, de imaginar figuras geométricas sem apresentar desenhos, ou apresentam figuras e esperam que o aluno busque conhecimentos geométricos para aplicar na situação.

As dificuldades apresentadas por grande parte dos alunos, desde os anos iniciais, apresentam como consequência a falta de interesse e até mesmo repulsa 
pela disciplina. Essa ideia corrobora para que a Matemática seja vista negativamente, muitas vezes aplicada de maneira inadequada ou mal interpretada.

Nas series iniciais do ensino fundamental a geometria é inserida no conteúdo escolar de forma gradativa, com noções básicas de retas, ângulos e algumas figuras geométricas como, por exemplo, círculos, quadrados e triângulos. No entanto, somente a partir do $8^{\circ}$ ano que são apresentadas as definições de retas, com seus axiomas, construção de ângulos e figuras geométricas, suas particularidades e condições de existência.

Para avançar no estudo da geometria os alunos precisam se familiarizar não apenas com os conhecimentos matemáticos básicos, mas também com instrumentos de medidas, como réguas, compassos, transferidores e esquadros. Em uma abrangência fora da sala de aula, o acesso a esses objetos possibilitará o manuseio de instrumentos profissionais como fitas métricas e trenas. Esse contato prático, além de aprofundar os estudos sobre a geometria, também trabalha a coordenação motora dos estudantes, que muitas vezes não é estimulada pelo professor, se esse apenas se detiver aos livros e não caminhar para a questão mais prática da geometria. Ressaltamos, portanto, a combinação da teoria aliada à prática para que o estudo da geometria não seja apenas uma abstração para o aluno.

\subsection{Desenvolvimento do Teodolito}

Desde a antiguidade as civilizações já se preocupavam em demarcar seus territórios e estudavam o solo para realizar suas plantações e construções. Estas atividades são características da ciência que hoje é conhecida como topografia. A partir dessas necessidades os povos antigos como egípcios, babilônicos e gregos desenvolveram mecanismos rudimentares, mas que serviram como base para aparelhos sofisticados que existem atualmente, dentre os quais podem ser destacados:

- Groma: Acredita-se que este instrumento teve origem na Mesopotâmia, por volta de 400 a.C. Na construção de suas obras, conhecidas pelas perfeições de linha e 
ângulos, os Gregos e Romanos utilizaram este instrumento. A figura 1.0 exemplifica sua utilização:

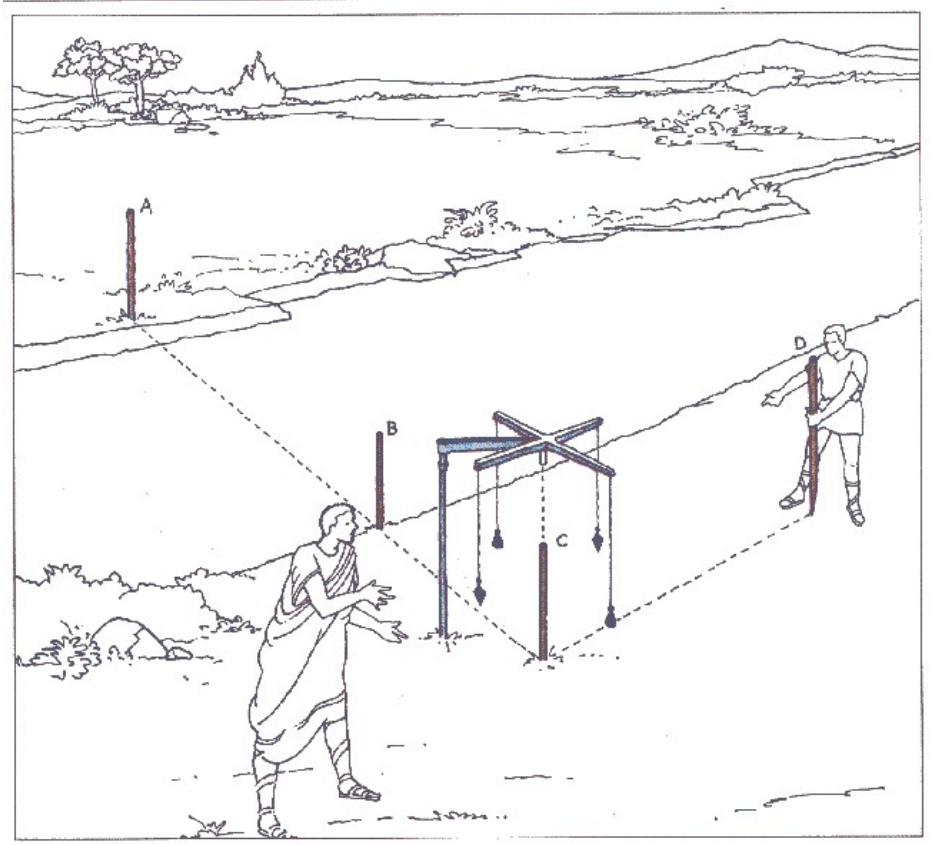

Figura 1.0 - Utilização da Groma

Fonte: (MUELANER, 2015)

- Dioptra: Este instrumento servia para medir ângulos e nivelamento, seu princípio para medir o nivelamento era a utilização de um tubo em formato de $U$ com água $e$ com a graduação era possível medir ângulos nos eixos vertical e horizontal, como pode ser visualizado na figura 1.2:

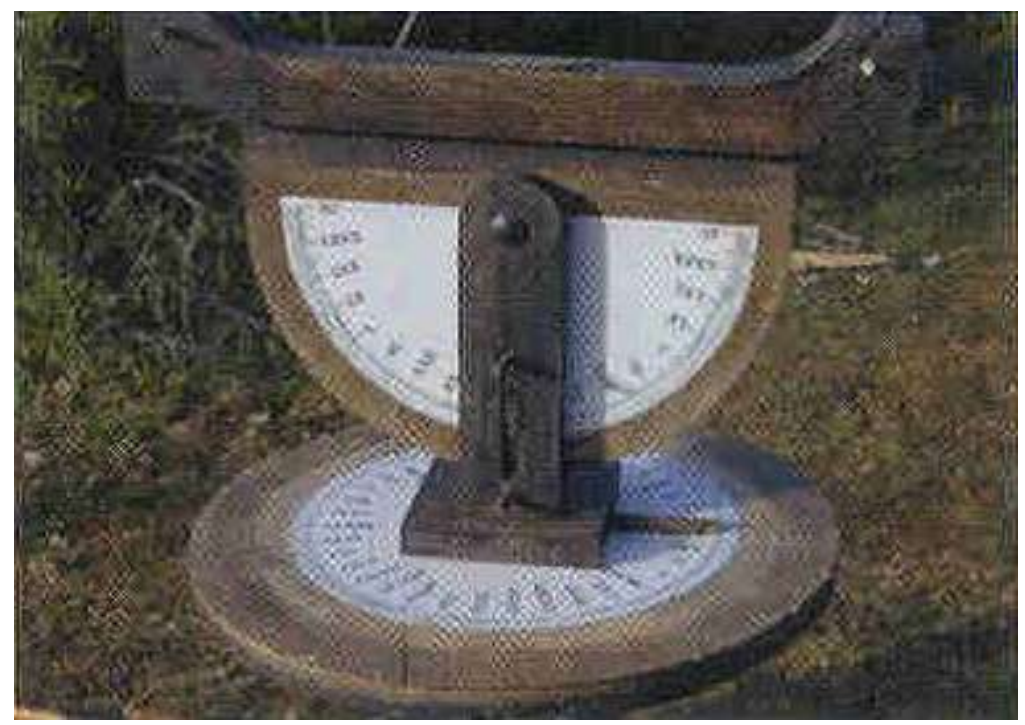

Figura 1.2 - Imagem de um Dioptra

Fonte: (SOUZA, 2012) 
- Quadrante: Como o nome sugere, seu formato consiste em um quarto de círculo graduado, tendo um fio de prumo fixo, como pode ser visto na figura 1.3. Sua principal utilização é a medição de alturas em relação ao horizonte, usando como base a distância angular. Passou a ser empregado na navegação, utilizando como referência a Estrela Polar e o Sol, ambos medidos em relação ao horizonte, sendo possível verificar se a embarcação estava mais a Sul ou ao Norte.

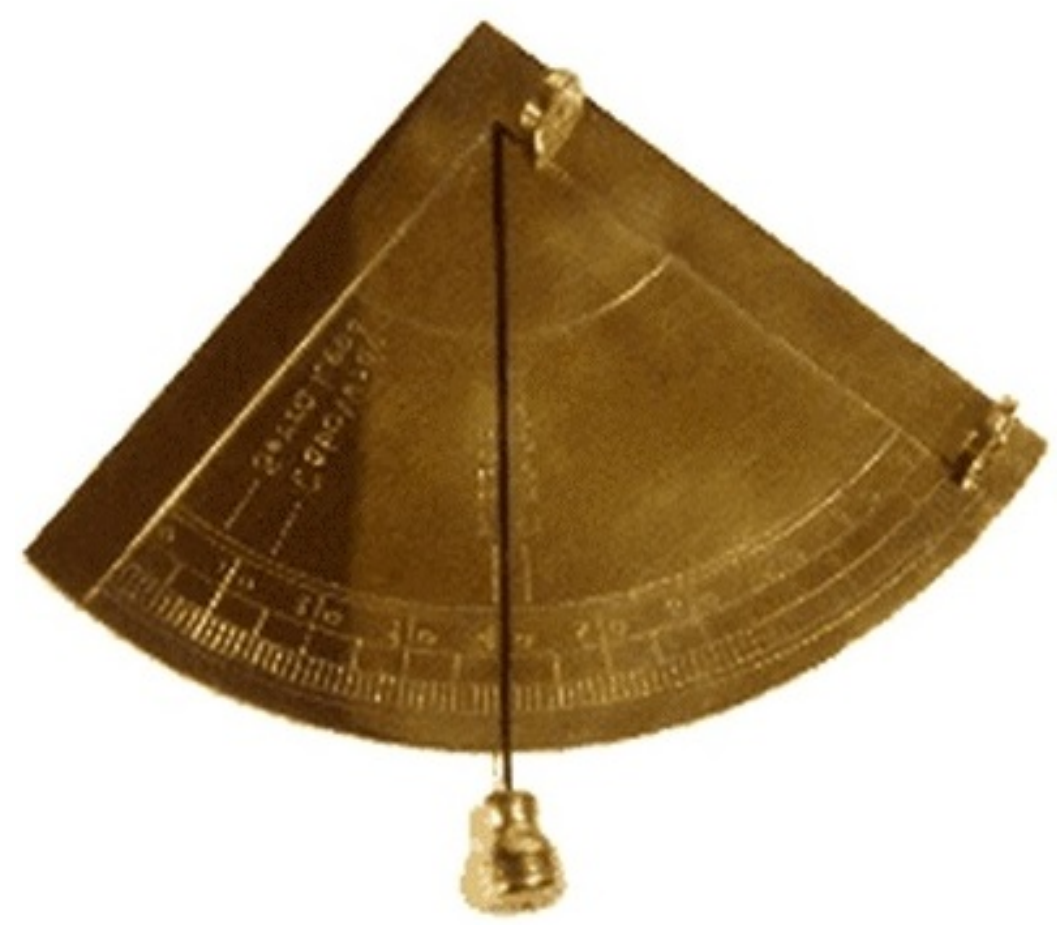

Figura 1.3 - Quadrante feito de bronze

Fonte: (HIRONDINO, 2012)

- Astrolábio: Este instrumento também foi bastante utilizado na navegação, pois é possível determinar a posição dos astros no céu. O modelo planisférico, mais antigo, foi inventado pelos gregos e alexandrinos, em cerca de 150 a.C. Já o modelo esférico foi construído em 1480. Este modelo foi usado no ensino de astronomia e explica as estações do ano, além de outros campos da mecânica celeste. A esfera central representa a Terra, que de acordo com o modelo Geocêntrico de Ptolomeu representava o centro do universo. A figura 1.4 apresenta os Astrolábio planisférico e esférico. 

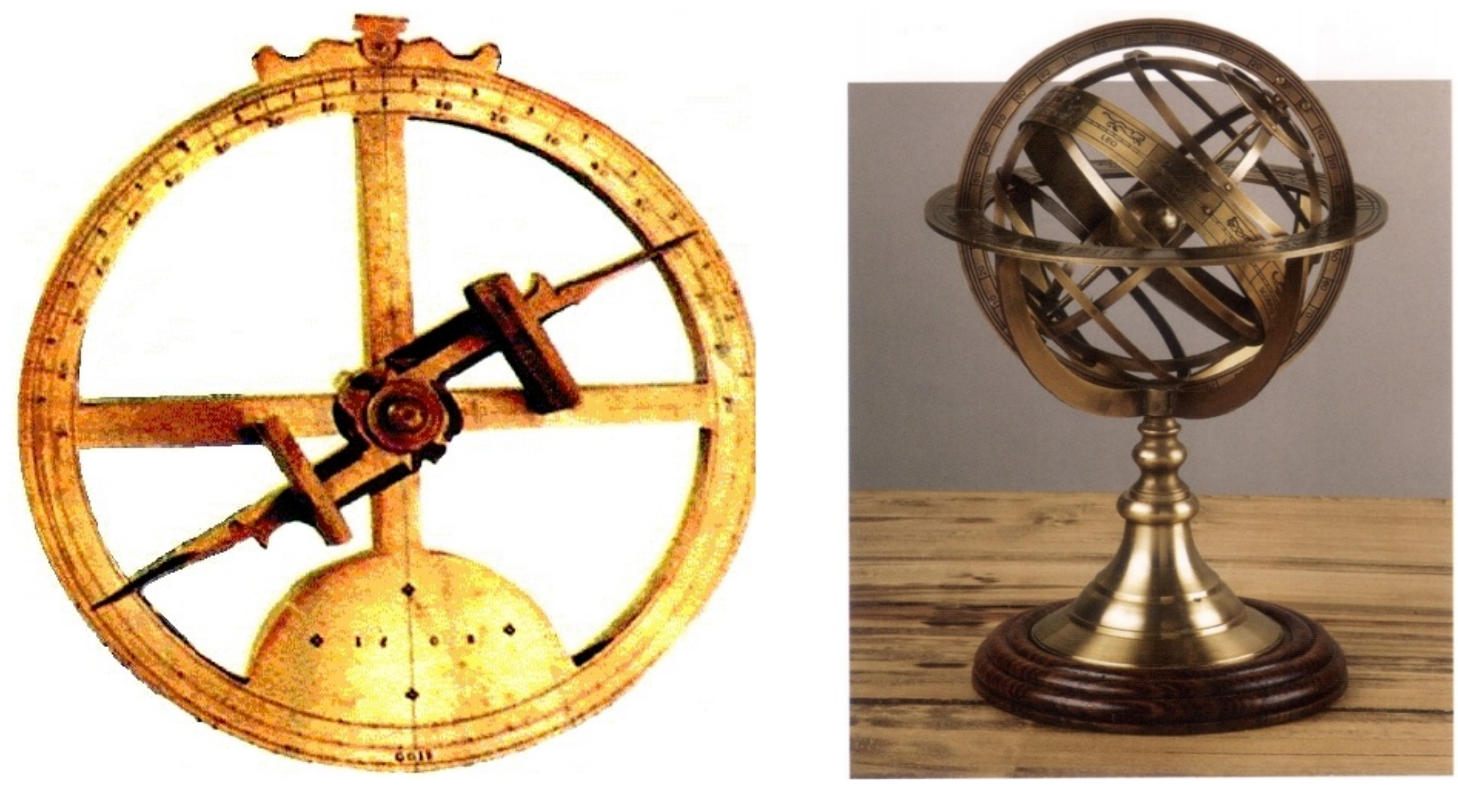

Figura 1.4 - Astrolábio planisférico e esférico

Fonte: (LAVANHA, 2012)

Os instrumentos citados mostram a evolução dos instrumentos utilizados na topografia. De acordo com Zilkha (2014), em 1720 Jonathan Sisson construiu o primeiro Teodolito que inicialmente possuía 4 parafusos niveladores. A figura 1.5 mostra um Teodolito do século XIX.

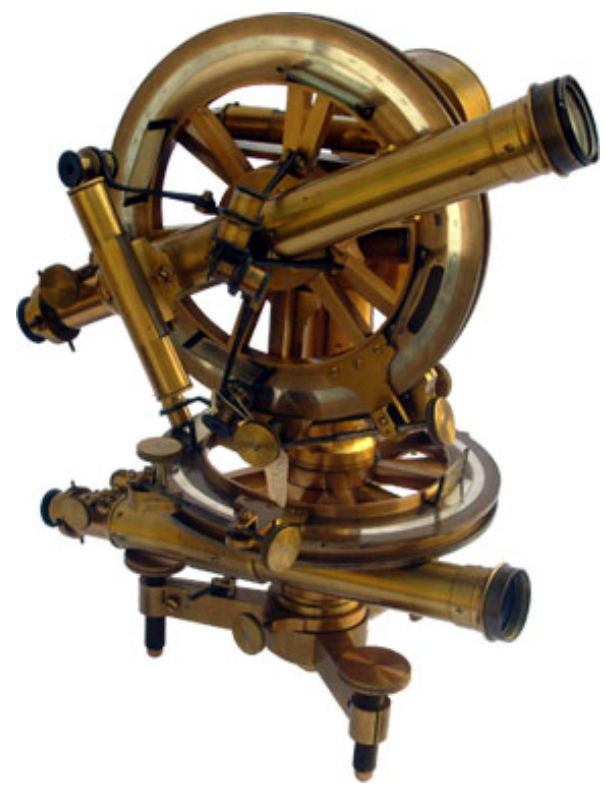

Figura 1.5 - Teodolito do século XIX exposto no acervo Museu de Astronomia e Ciências Afins.

Fonte: (GRANATO, 2010) 
O Teodolito apresentado na figura 1.5 funciona através da utilização de dois eixos perpendiculares e independentes. Em cada eixo possui uma lente de aumento que realiza movimento circular, podendo assim realizar leituras de ângulos nos planos horizontal e vertical.

Desde sua primeira construção o Teodolito vem passando por aprimoramentos e novos componentes foram agregados a fim de facilitar seu uso. A partir da década de 1970 começaram a aparecer os primeiros Teodolitos eletrônicos. Na figura 1.6 há dois Teodolitos, sendo um mecânico e o outro eletrônico.
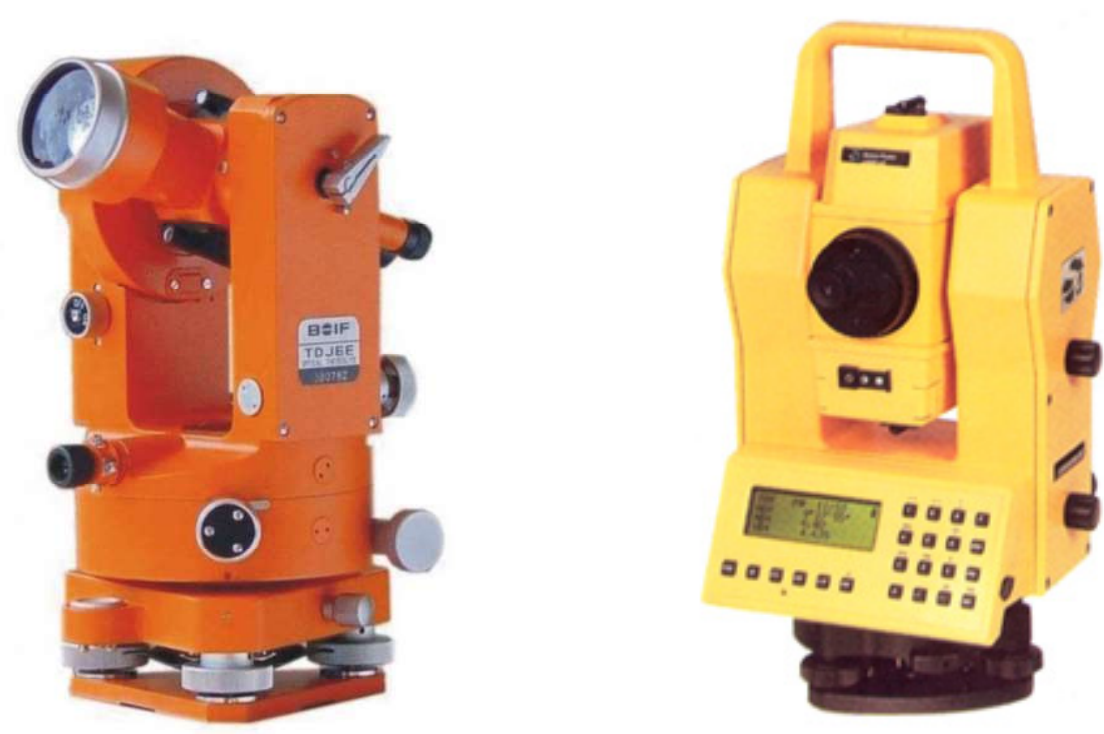

Figura 1.6 - Teodolito mecânico e eletrônico com visor de ângulos com display.

Fonte: (GRANATO, 2010)

O funcionamento do Teodolito eletrônico é praticamente o mesmo que o mecânico, com a diferença que o sistema de leitura ótica foi substituído por um sistema de captores eletrônicos, sendo que o valor da medida dos ângulos realizada pelo operador do aparelho aparece em um display. Além disso, o Teodolito eletrônico pode fazer o cálculo para o topógrafo, e o mecânico dá apenas as medidas dos ângulos, necessitando ainda aplicar Trigonometria (ZILKHA, 2014).

O Teodolito utiliza dois eixos perpendiculares entre si para realizar suas medidas, geralmente estes ângulos estão dispostos nas direções horizontal e vertical. Desta forma, o Teodolito é basicamente um telescópio montado sobre o tripé para nivelação e possui graduações para leitura de ângulos na horizontal e 
vertical, para que o usuário possa fazer as leituras. Na figura 1.7 há uma representação do movimento realizado pelos eixos.

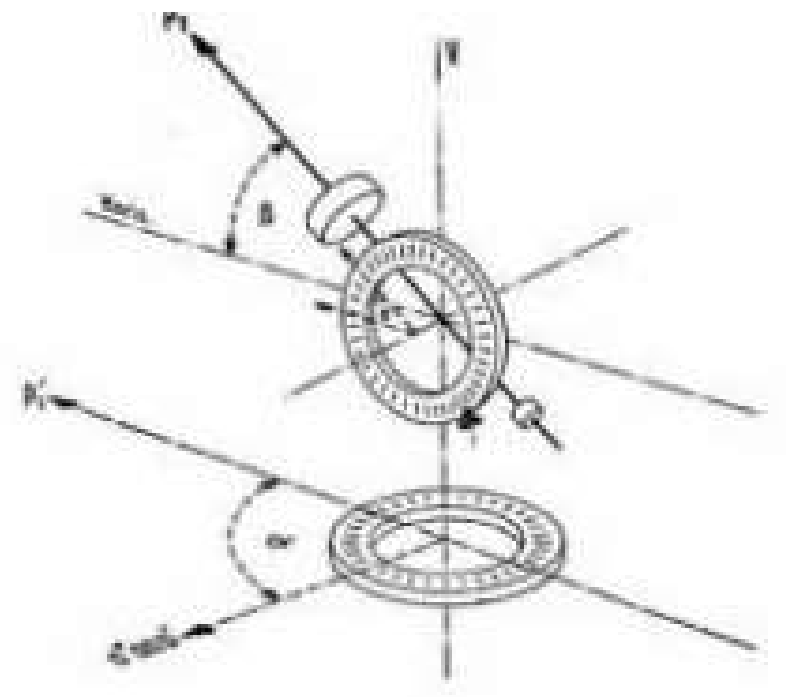

Figura 1.7 - Esquema do movimento circular das lentes do Teodolito.

Fonte: (ZILKHA, 2014)

Segundo Zilkha (2014) ao utilizar o Teodolito é necessário conhecer alguns termos em relação às leituras dos ângulos e certas distâncias:

- Azimute: é o ângulo horizontal, no sentido horário, tomado em relação ao Norte, como pode ser verificado na figura 1.8. O nome é de origem árabe, de assumut, "caminho ou direção".

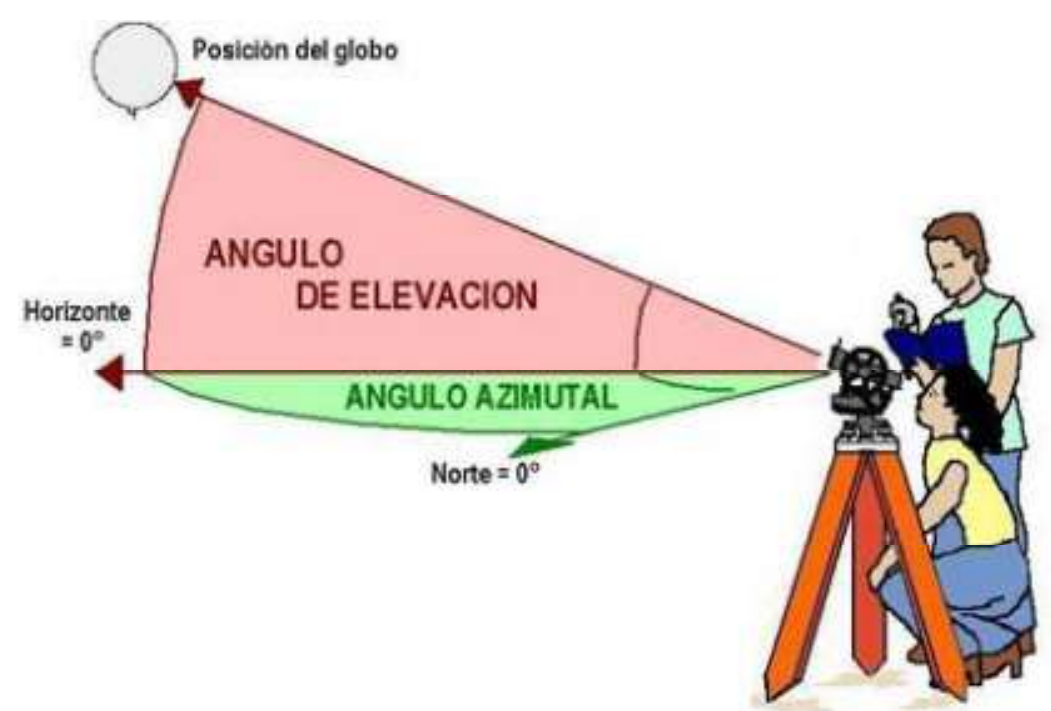

Figura 1.8 - Determinação do ângulo Azimute.

Fonte: (ZILKHA, 2014) 
- Ângulo Horizontal: é medido entre as projeções de dois alinhamentos do terreno, no plano horizontal. A figura 1.9 explica esta medida:

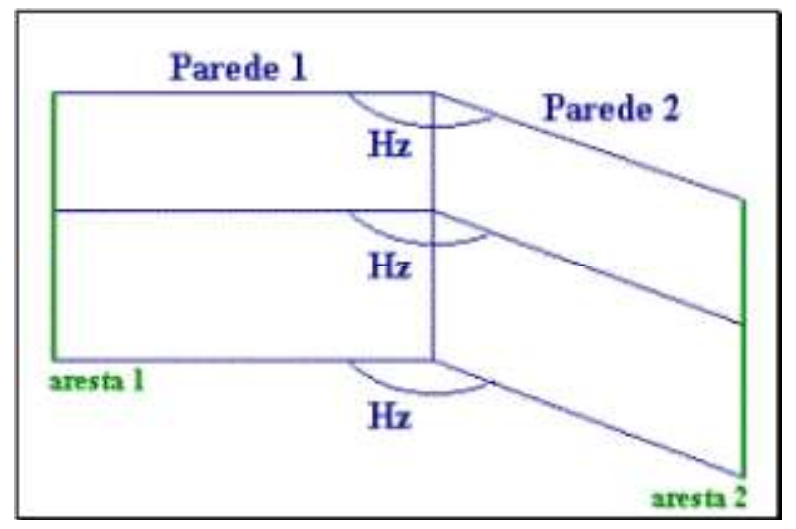

Figura 1.9 - Ângulo Horizontal

Fonte: (ZILKHA, 2014)

- Ângulo Vertical: é medido entre um alinhamento do terreno e o plano do horizonte. Pode ser ascendente, quando positivo, ou descendente, quando negativo, conforme se encontre acima (aclive) ou abaixo (declive) deste plano. A figura 1.10 exemplifica esta medida:

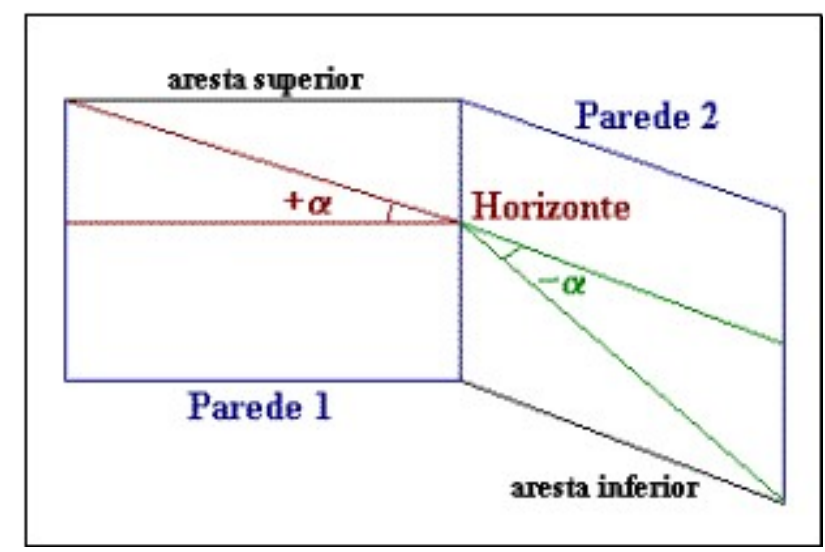

Figura 1.10 - Ângulo Vertical

Fonte: (ZILKHA, 2014)

- Distância Horizontal: é a distância medida entre dois pontos, no plano horizontal. Na figura 1.11 está indicada por $\mathrm{DH}$. 
- Distância Vertical ou Diferença de Nível: é a distância medida entre dois pontos, num plano vertical que é perpendicular ao plano horizontal. Na figura 1.11 está indicada por DV.

- Distância Inclinada: é a distância medida entre dois pontos, em planos que seguem a inclinação da superfície do terreno. Na figura 1.11 está indicada por DI.

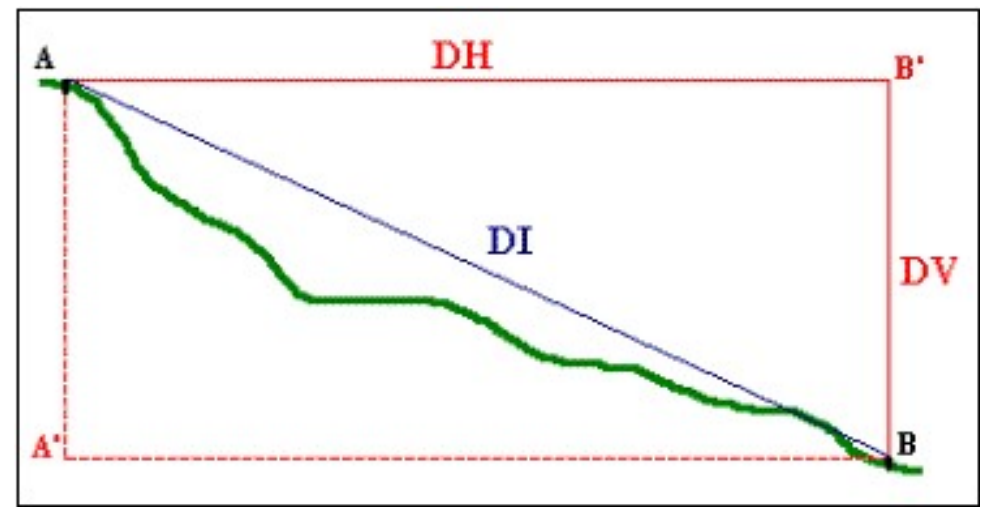

Figura 1.11 - Distância horizontal, vertical e inclinada.

Fonte: (ZILKHA, 2014)

\subsection{Modelagem Matemática}

A Matemática faz parte de nosso cotidiano e está presente na simplicidade das brincadeiras infantis, na divisão de grupos, na contagem de figurinhas, bem como nas atividades realizadas por adultos, como o ato de fazer compras ou no planejamento orçamentário familiar. A Matemática, portanto, possui inúmeras formas de aplicação, e está por toda a parte.

Ainda que isso seja um fato em nossa vida cotidiana, muitas vezes as pessoas não conseguem aplicar esses conceitos às suas necessidades. $\mathrm{Na}$ escola, por exemplo, muitas vezes os alunos enxergam a Matemática com algo difícil e complexo porque não encontram sentido prático nos seus estudos. É imprescindível que a Matemática seja contextualizada, deixando de ser uma disciplina abstrata para os estudantes sintam-se de alguma forma atraídos por ela.

Uma forma de mostrar ao aluno que a Matemática não é uma disciplina desconexa das demais é utilizando a Modelagem Matemática. Ela é uma área do conhecimento que estuda a simulação de sistemas reais a fim de prever o 
comportamento dos mesmos, sendo empregada em várias áreas do conhecimento. A modelagem Matemática é uma tentativa de se descrever os fenômenos da natureza matematicamente.

De acordo com Viecili (2006) essa área teve início na década de 1980, tanto no âmbito profissional como no acadêmico. Foi um campo bastante impulsionado devido ao grande avanço tecnológico na área da informática. Desde atividades do nosso cotidiano até atividades complexas na área da indústria passaram a ser realizadas por máquinas através do uso de computadores, dando origem ao termo "Era da Informática".

O uso de máquinas proporcionou, além de ganho físico, grande agilidade na realização de cálculos complexos que manualmente seriam realizados em horas ou até mesmo dias. Em contrapartida essa facilidade na realização de certas atividades ocasionou em grande parte a desvalorização de conhecimentos matemáticos, onde as pessoas muitas vezes recorrem ao uso rápido de uma calculadora, mas não sabem resolver um exercício numérico em uma folha de papel.

Essa realidade abre precedentes para outros questionamentos, como a função da escola em assumir metodologias de ensino e aprendizagem que, ao invés de afastar os alunos dos bancos escolares, possa justamente dialogar com suas atividades cotidianas.

Quando o professor aplica no ambiente escolar as situações do cotidiano o conhecimento passa a fazer sentido. Para isso é necessário conciliar a realidade dos alunos com o conteúdo que será estudado, aproveitando as experiências fora do contexto escolar dos estudantes como ponto de interesse comum do grupo.

Gazetta (1989) elucida os principais benefícios de trabalhar com a modelagem Matemática em sala de aula:

- Motivação dos alunos e do próprio professor;

- Facilitação da aprendizagem. O conteúdo matemático passa a ter significação, deixa de ser abstrato e passa a ser concreto;

- Preparação para futuras profissões nas mais diversas áreas do conhecimento, devido à interatividade do conteúdo matemático com outras disciplinas;

- Desenvolvimento do raciocínio, lógico e dedutivo em geral; 
- Desenvolvimento do aluno como cidadão crítico e transformador de sua realidade;

- Compreensão do papel sócio-cultural da Matemática, tornando-a assim, mais importante.

Apesar dos benefícios citados, aplicar a modelagem Matemática em sala de aula não é uma tarefa tão simples para o professor. Há muitos obstáculos que dificultam a abordagem desse conceito como falta de tempo, falta de condições físicas e financeiras, cobranças de outras ordens que distanciam o professor do preparo de aulas mais práticas e menos teóricas.

A modelagem Matemática é uma metodologia alternativa para o ensino de Matemática que pode ser utilizada tanto no ensino fundamental como no ensino médio. A partir de conceitos gerais, procura-se mostrar a importância da Matemática para o conhecimento e compreensão da realidade onde se vive. Uma forma de avaliar se a modelagem Matemática é eficiente no processo de ensinoaprendizagem é estabelecer um paralelo entre o ensino tradicional e o ensino através da modelagem Matemática, abordando aspectos como a pedagogia adotada, a criatividade, o interesse pelo estudo de Matemática, a motivação e entusiasmo por parte dos alunos e a avaliação do que eles realmente aprenderam com a Modelagem Matemática, levando o professor a refletir sobre a sua metodologia de ensino da Matemática.

É evidente que ela não deve ser usada como uma única metodologia de ensino. O professor, no exercício das suas atividades, deve sempre procurar a metodologia mais adequada de ensino da Matemática de acordo com sua realidade. Podemos citar alguns exemplos: jogos lúdicos, histórias envolvendo a Matemática, resolução de problemas, testes matemáticos, campeonatos, olimpíadas estudantis, enfim, usar todos os seus recursos para obter o melhor resultado possível no ensino da Matemática. 


\subsection{Aplicações do Teodolito no contexto escolar}

Teodolito é um instrumento usado para medição, utilizado principalmente em estudos topográficos ou análise de dimensões de locais inacessíveis. Ele pode tanto ser usado para medidas de ângulos horizontais como verticais, embora meçam com mais precisão os ângulos verticais. Um exemplo prático de sua aplicação é a medição da distância entre as margens de um rio, onde é necessário realizar medidas indiretas aplicando conceitos da geometria.

Neste caso, procura-se criar figuras geométricas utilizando pontos de referência e com distâncias ou ângulos conhecidos, utilizando conhecimentos matemáticos. É possível, assim, calcular as dimensões desejadas com o uso do Teodolito, obtendo as relações existentes em triângulos. Como no exemplo citado, se fosse necessário obter a distância entre as margens de um rio, poderia representar a medição no seguinte esquema:

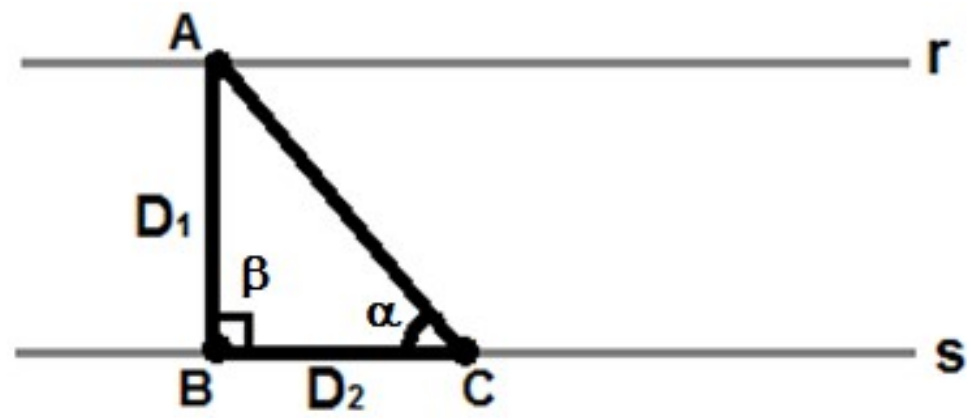

Figura 1.12 - Desenho de um triângulo imaginário formado a partir de pontos nas margens de um rio.

Supondo que as retas $r$ e $s$ sejam as margens de um rio, $D_{2}$ a distância conhecida entre dois pontos $B$ e $C$ de uma mesma margem do rio e o ponto $A$ na outra margem do rio. Os ângulos $\alpha$ e $\beta$ podem ser obtidos usando o Teodolito. Para agilizar o cálculo é possível utilizar pontos que formem um triângulo retângulo, no caso da figura os pontos $A$ e $B$ estão formando um segmento de reta $\overline{A B}$ perpendicular à margem do rio, ou seja, o ângulo $A \hat{B} C$ possui $90^{\circ}$. Desta forma, $D_{1} \mathrm{e}$ $D_{2}$ são os catetos do triângulo retângulo e $D_{1}$ coincide com a distância entre as margens do rio.

Se este problema fosse apresentado a alunos de Ensino Médio, que já possuem conhecimento em trigonometria, a resolução seria bem simples: 


$$
D_{1}=D_{2} \cdot \tan \alpha
$$

Usando uma calculadora ou uma tabela trigonométrica é possível obter o valor da tangente do ângulo $\alpha(\tan \alpha)$ e multiplicando por $D_{2}$ teria o valor procurado.

Caso o problema fosse apresentado a alunos que ainda não possuem conhecimentos em trigonometria, poderia ser obtido usando relações de semelhança de triângulos. Este caso será apresentado nas próximas seções, pois se refere à parte do procedimento realizado pelos alunos relacionados neste trabalho.

Há uma variação desse problema: supondo que não fosse possível medir o tamanho de nenhum dos lados do triângulo, neste caso não teríamos o valor conhecido de $D_{2}$.

Por exemplo, se fosse necessário calcular a altura de uma montanha, não seria possível "criar" o triângulo do exemplo anterior, pois o ponto B estaria inacessível. Neste caso é necessário realizar medidas em dois locais diferentes com o Teodolito, como o interesse é saber a altura da montanha, as duas leituras devem ser feitas usando o mesmo ponto $A$ que representa o topo da montanha na figura 1.13 .

Na mesma figura, os pontos $C$ e $D$ são os locais onde seriam feitas a leituras com o Teodolito e os mesmos determinam a distância $D_{2}$, medida que poderia ser obtida facilmente. $O$ ponto $B$ é inacessível, mas ele é obtido usando uma linha imaginária que passa pelo ponto $A$ e é perpendicular à reta $r$, que na imagem representa o solo, o ponto $B$ é o ponto de intersecção das retas que o segmento $\overline{A B}$ pertence com a reta $r . D_{3}$ é uma distância de medida inacessível, apesar de seu valor não ser necessário para obter o valor da altura da montanha $\left(D_{1}\right)$ é uma parte importante para resolução do problema. 


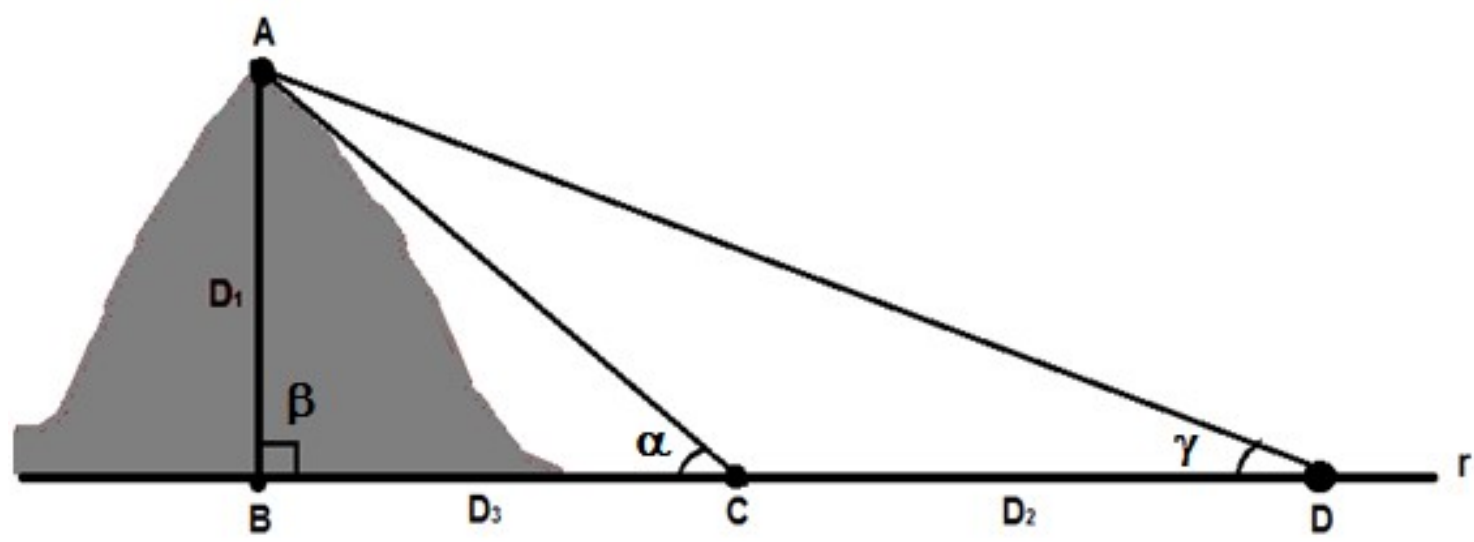

Figura 1.13 - Desenho de triângulos para calcular a altura de uma montanha.

Como pode ser observado na figura 1.13, há dois triângulos retângulos: $A B C$ e $A B D$, ambos possuem o ângulo $\beta$ em comum, que para facilitar os cálculos foi construído com o valor de $90^{\circ}$.

Como há duas medidas desconhecidas $\left(D_{1}\right.$ e $\left.D_{3}\right)$ é necessário resolver um sistema de equações com duas incógnitas. Aplicando este problema a alunos do Ensino Médio as seguintes equações podem ser obtidas:

- Utilizando o triangulo ABC:

$$
\tan \alpha=\frac{D_{1}}{D_{3}} \rightarrow D_{3}=\frac{D_{1}}{\tan \alpha}
$$

- Utilizando o triângulo ABD:

$$
\tan \gamma=\frac{D_{1}}{D_{3}+D_{2}} \rightarrow D_{3}+D_{2}=\frac{D_{1}}{\tan \gamma} \rightarrow D_{3}=\frac{D_{1}}{\tan \gamma}-D_{2}
$$

Igualando as equações (1.2) e (1.3) obtemos a seguinte relação:

$$
\frac{D_{1}}{\tan \alpha}=\frac{D_{1}}{\tan \gamma}-D_{2} \rightarrow D_{2}=\frac{D_{1}}{\tan \gamma}-\frac{D_{1}}{\tan \alpha} \rightarrow
$$




$$
D_{2}=D_{1}\left(\frac{1}{\tan \gamma}-\frac{1}{\tan \alpha}\right) \rightarrow D_{1}=D_{2}\left(\frac{\tan \alpha \cdot \tan \gamma}{\tan \alpha-\tan \gamma}\right)
$$

E novamente, neste caso, utilizando uma calculadora ou tabela trigonométrica seria possível obter os valores das tangentes e assim calcular o valor $D_{1}$.

Para alunos que não conhecem a trigonometria, a resolução também poderia ser realizada com o uso de semelhança de triângulos, que será discutido nas próximas seções. Existem várias aplicações do uso do Teodolito, mas a maioria recorre às duas situações citadas anteriormente. 


\section{MATERIAIS E MÉTODOS}

Para desenvolver o trabalho de construção do Teodolito com os alunos foi necessário dividi-lo em etapas: "Construção do Teodolito"; "Utilização do Teodolito" e "Cálculo para obtenção do valor referente ao tamanho de uma região inacessível ou de grande extensão utilizando construção de figuras geométricas a partir de observações realizadas com o Teodolito". Nesta seção, ainda foram apresentados os cálculos necessário para verificar a qualidade dos valores obtidos pelos alunos. Desta forma, esta seção será apresentada em quatro tópicos, para que cada etapa seja explicada da forma mais clara possível.

\subsection{Construção do Teodolito "caseiro"}

Durante as aulas teóricas foram apresentadas situações problemas para determinar o tamanho de construções que nos cercam em nosso cotidiano. Em certo momento ficou claro que só era possível obter o tamanho de determinadas regiões utilizando métodos geométricos, recorrendo a instrumentos de leitura de ângulos. Para isso, os alunos deveriam relacionar a região a ser mensurada com polígonos. Dentre outros exemplos pode-se verificar que esta dificuldade aparece quando queremos determinar o valor da distância entre as margens de um rio muito largo ou a altura de um prédio ou montanha.

Após definir a parte teórica e citar alguns exemplos e aplicações práticas de situações cotidianas que envolvessem a leitura de ângulos utilizando material escolar, foi sugerida a construção de um Teodolito "caseiro". Dessa forma, para construir o Teodolito cada aluno utilizou os seguintes materiais:

- Um pedaço retangular de papel cartão ou papelão de dimensões aproximadamente $40 \mathrm{~cm} \times 30 \mathrm{~cm}$;

- Uma figura de transferidor escolar de formato circular com raio de medida aproximada de $25 \mathrm{~cm}$;

- Um copo descartável com tampa; 
- Um canudo (utilizado para beber liquido);

- Um pedaço de arame maleável de aproximadamente $15 \mathrm{~cm}$;

- Cola escolar;

- Cola quente, aplicável com uso de pistola elétrica;

- Fita adesiva - Durex;

- Tesoura escolar.

Para obtenção dos materiais utilizados na construção do Teodolito foi feito um acordo com os alunos que o material descartável (copo com tampa, canudo e arame) seria de responsabilidade de cada estudante, pois isso colaborou tanto no sentido de proporcionar um baixo custo da experiência, como o reaproveitamento dos materiais como incentivo para a reciclagem dos mesmos. O restante dos materiais foi fornecido pelo professor e pela Unidade Escolar. Alguns alunos não conseguiram obter todo material reciclável até o dia da construção do Teodolito, para que eles não ficassem impossibilitados da participação foram fornecidos os materiais faltantes aos mesmos.

Os alunos foram aconselhados a utilizarem o seguinte roteiro para construção do Teodolito:

- $1^{\mathrm{a}}$ etapa - Recortar a figura do transferidor de formato circular;

- $2^{a}$ etapa - Recortar o papel cartão ou papelão no formato retangular de dimensões aproximadamente de $40 \mathrm{~cm} \times 30 \mathrm{~cm}$;

- $\quad 3^{a}$ etapa - Colar a figura do transferidor circular no papel cartão;

- $4^{a}$ etapa - Colar a tampa do copo descartável de formato circular na região central da figura do transferidor, utilizando cola quente;

- $5^{\mathrm{a}}$ etapa - Furar o copo descartável próximo do lado aberto, ao longo de seu diâmetro usando o pedaço de arame e fixando-o ao mesmo;

- $6^{a}$ etapa - Fixar com fita adesiva a lateral do canudo ao lado externo da base do copo descartável;

- $7^{\mathrm{a}}$ etapa - Encaixar a tampa no copo. 
Cada aluno recebeu uma folha de papel com a imagem de um transferidor de $360^{\circ}$ com aproximadamente $25 \mathrm{~cm}$ de raio e com o uso da tesoura escolar a imagem foi recortada, como ilustra a figura 2.1.

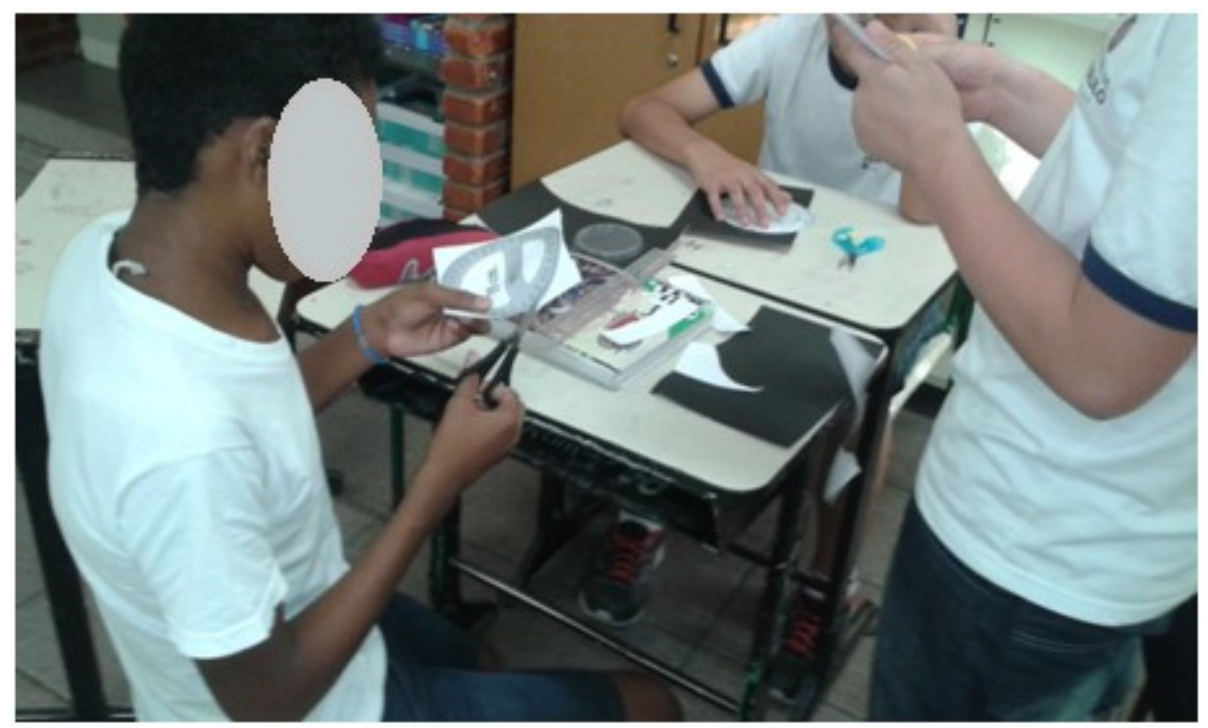

Figura 2.1 - Alunos recortando a imagem do transferidor.

Ao final da $1^{\text {a }}$ etapa cada aluno obteve uma das duas imagens representadas na figura 2.2 .
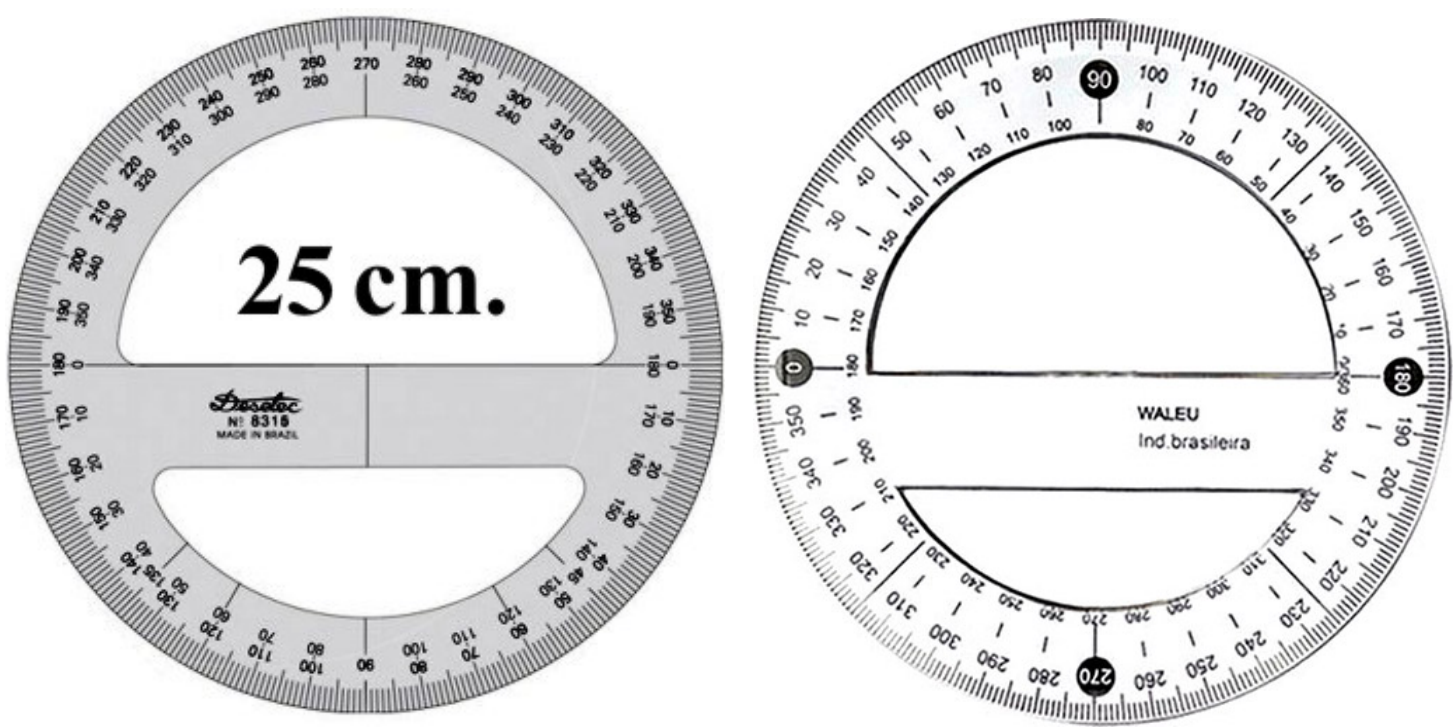

Figura 2.2 - Imagens resultantes da $1^{a}$ etapa do roteiro de construção do Teodolito.

A etapa seguinte foi o recorte do papel cartão em formato retangular. Em seguida a imagem do transferidor foi colada no papel cartão. Este procedimento foi 
necessário, pois o papel cartão serviu de apoio para a figura do transferidor, pois durante a utilização do Teodolito era necessário que o leitor, no caso a figura do transferidor, não mudasse de posição durante o processo e o papel cartão cumpriu com esta tarefa. Na figura 2.3 é possível observar o desenvolvimento dos alunos nesta etapa.
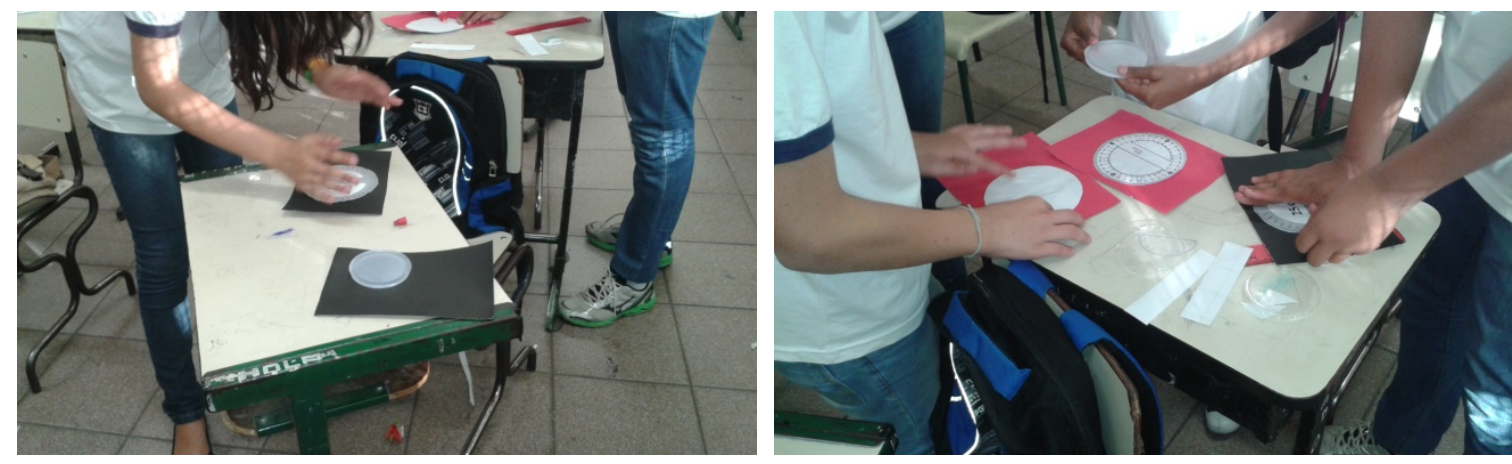

Figura 2.3 - Alunos colando a imagem do transferidor no papel cartão retangular.

$\mathrm{Na} 4^{\mathrm{a}}$ etapa os alunos colaram a tampa do copo descartável na imagem do transferidor. Neste momento foi esclarecido aos alunos que era importante que o centro da tampa coincidisse com o centro da figura do transferidor, para que o Teodolito fosse construído de forma simétrica. Para realizar esta colagem foi necessário utilizar cola quente, a qual foi manuseada pelos próprios alunos, seguindo as orientações do professor.
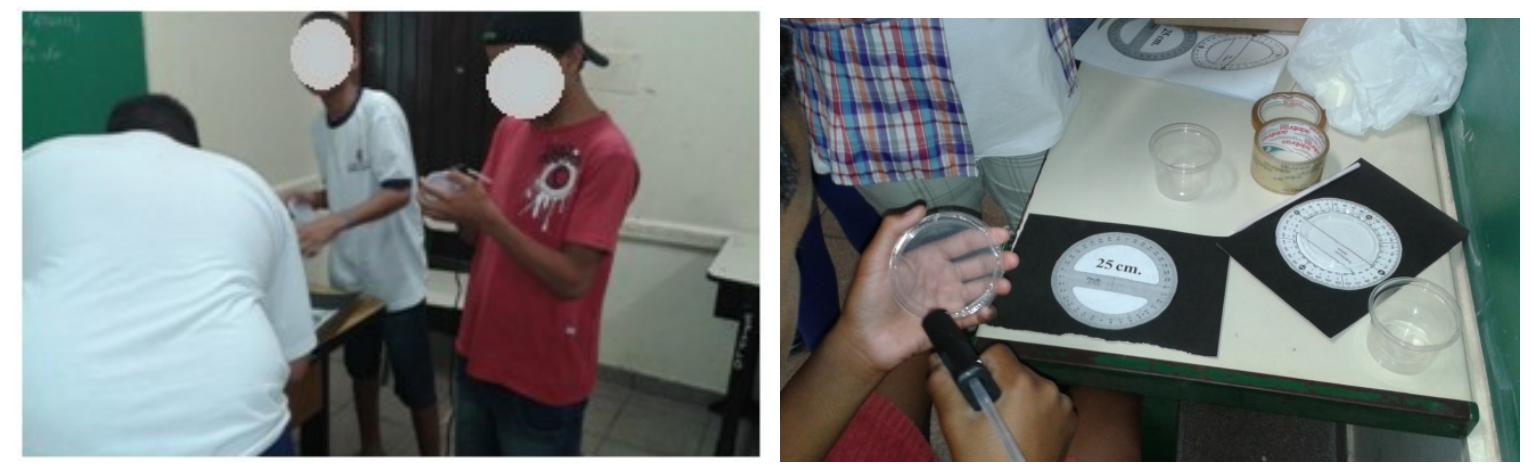

Figura 2.4 - Alunos utilizando cola quente para colar a tampa do copo descartável.

As etapas finais foram destinadas a fixação de itens utilizados para facilitar a visualização da leitura dos ângulos. $\mathrm{Na} 5^{\mathrm{a}}$ etapa foi explicada aos alunos a importância de que a posição do pedaço de arame coincidisse com a linha 
imaginária que passa pelo diâmetro do copo e na $6^{\mathrm{a}}$ etapa para que a leitura dos ângulos realizada no Teodolito fosse a mais eficiente possível era necessário que o canudo estivesse paralelo ao pedaço de arame. Estes procedimentos estão exibidos na figura 2.5 .

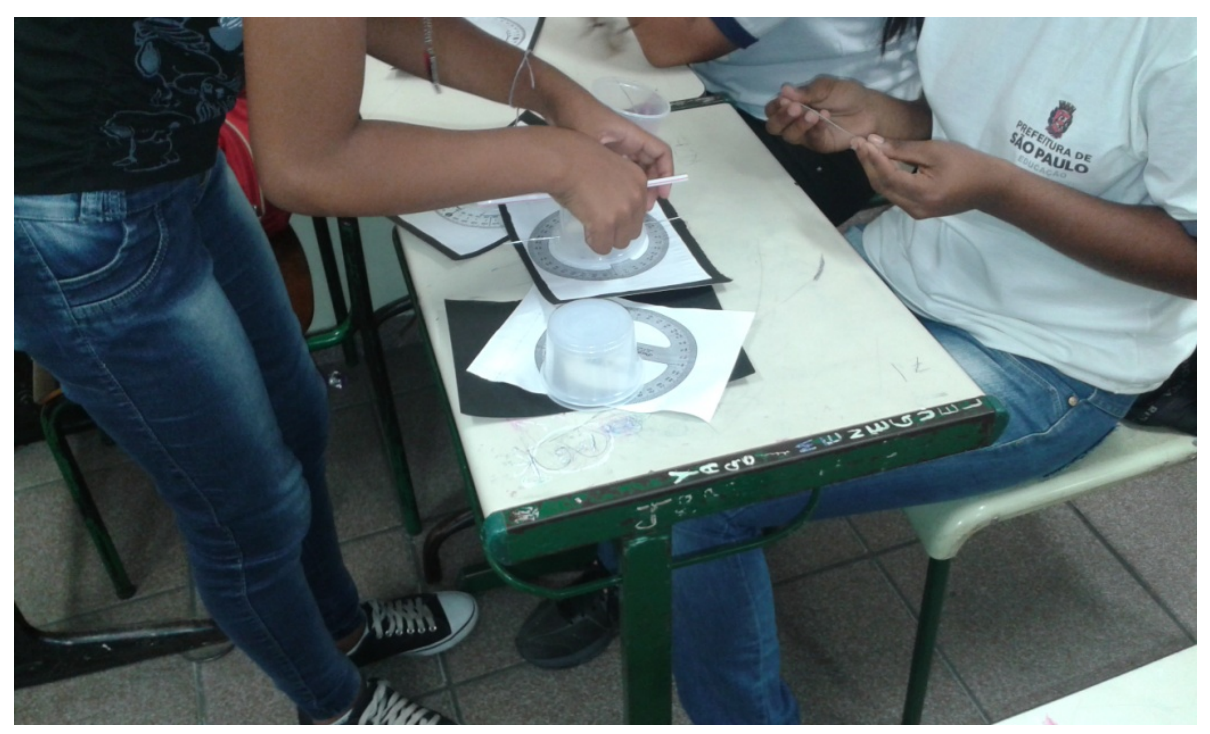

Figura 2.5 - Fixação do pedaço de arame e do canudo no Teodolito.

A $7^{\text {a }}$ etapa foi apenas para juntar as partes do Teodolito. Ao final desta etapa os alunos conseguiram alcança o objetivo de construção do Teodolito. Alguns Teodolitos estão expostos na figura 2.6 .
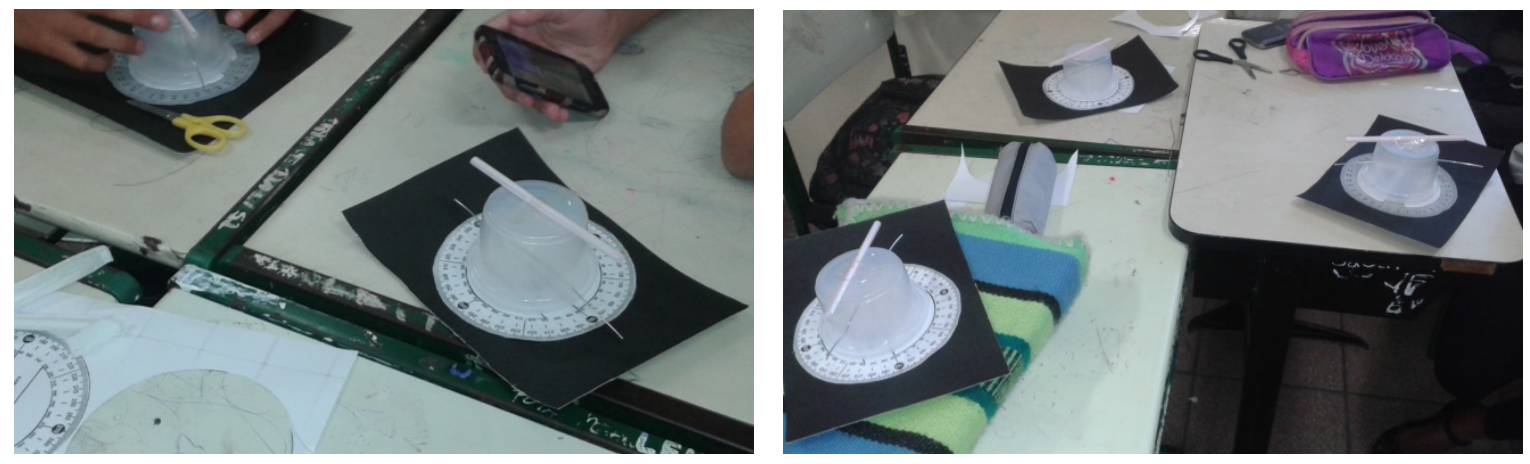

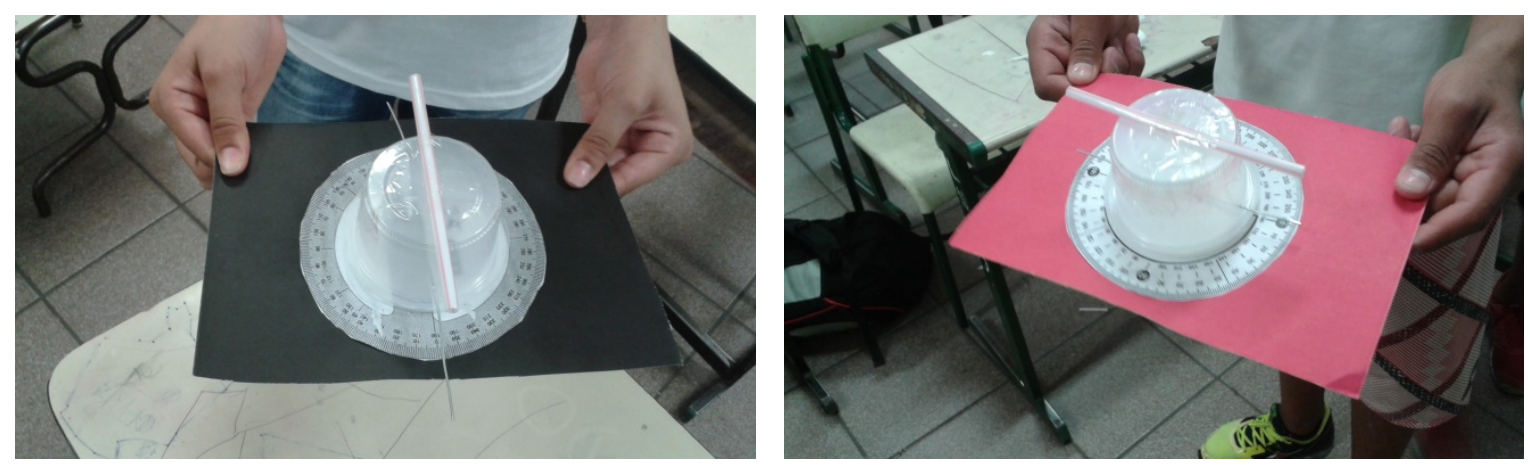

Figura 2.6 - Resultado final da construção do Teodolito.

Todo o processo de construção do Teodolito, incluindo o período usado para organização da sala de aula, recortes e tempo para aquecimento da cola quente durou cerca de duas aulas (90 minutos), sendo registrado por fotos como é possível ver por meio das figuras.

\subsection{Utilização do Teodolito "caseiro"}

Os alunos realizaram treinos antes da aula prática, que consistiu na exploração do ambiente externo da escola (pátio descoberto) para realizar a atividade. Desse modo, puderam tirar dúvidas que eventualmente iam acontecendo durante a construção do Teodolito.

\subsubsection{Esclarecimentos da utilização do Teodolito}

Após a etapa de construção do Teodolito em sala de aula foram realizadas demonstrações sobre sua utilização. A principal ideia é que os alunos pudessem verificar na prática como é possível usar esse aparelho que foi construído por eles mesmos.

O principal objetivo com a construção do Teodolito foi estimar a altura de objetos presentes no cotidiano dos alunos. Durante a aula prática os alunos puderam verificar que para realização das leituras através do Teodolito em relação ao solo seria necessário fazer cálculos matemáticos. Ainda em sala de aula os 
alunos realizaram medidas para simular a obtenção do valor da altura de uma parede, para que na parte prática já pudessem estar mais familiarizados com a utilização do instrumento.

Inicialmente foi escolhido um anteparo para que o Teodolito ficasse apoiado, e assim não ocorresse variação de altura em relação ao solo durante as leituras. Cada aluno anotou o valor da altura do anteparo em relação ao solo. Foi pedido que os alunos fizessem uma marca de mesma altura no local que seria visualizado pelo Teodolito. Foi usada uma carteira escolar como apoio para o Teodolito, cuja altura é de aproximadamente um metro em relação ao solo, altura essa marcada na parede onde seriam realizados os testes.

Em seguida os alunos foram instruídos a observarem por dentro do canudo do Teodolito na direção da parede a ser calculada a altura. A primeira leitura realizada pelos alunos foi apontando o canudo na direção da marcação da altura feita na parede. O valor do ângulo observado no Teodolito foi marcado. Esse procedimento foi necessário, pois os alunos colaram as figuras do transferidor em posições variadas.

Posteriormente uma nova leitura foi feita, agora com o leitor do Teodolito apontado para o ponto mais alto da parede; o valor da leitura também foi marcado. Foi feita a subtração entre as duas medidas para ser utilizada apenas a variação angular do Teodolito nos cálculos. Por exemplo, um aluno que obtivesse na primeira leitura $5^{\circ}$ e na segunda leitura $30^{\circ}$, o valor a ser usado nos cálculos seria $30^{\circ}-5^{\circ}=25^{\circ}$. Um exemplo de leitura está representado na figura 2.7: 


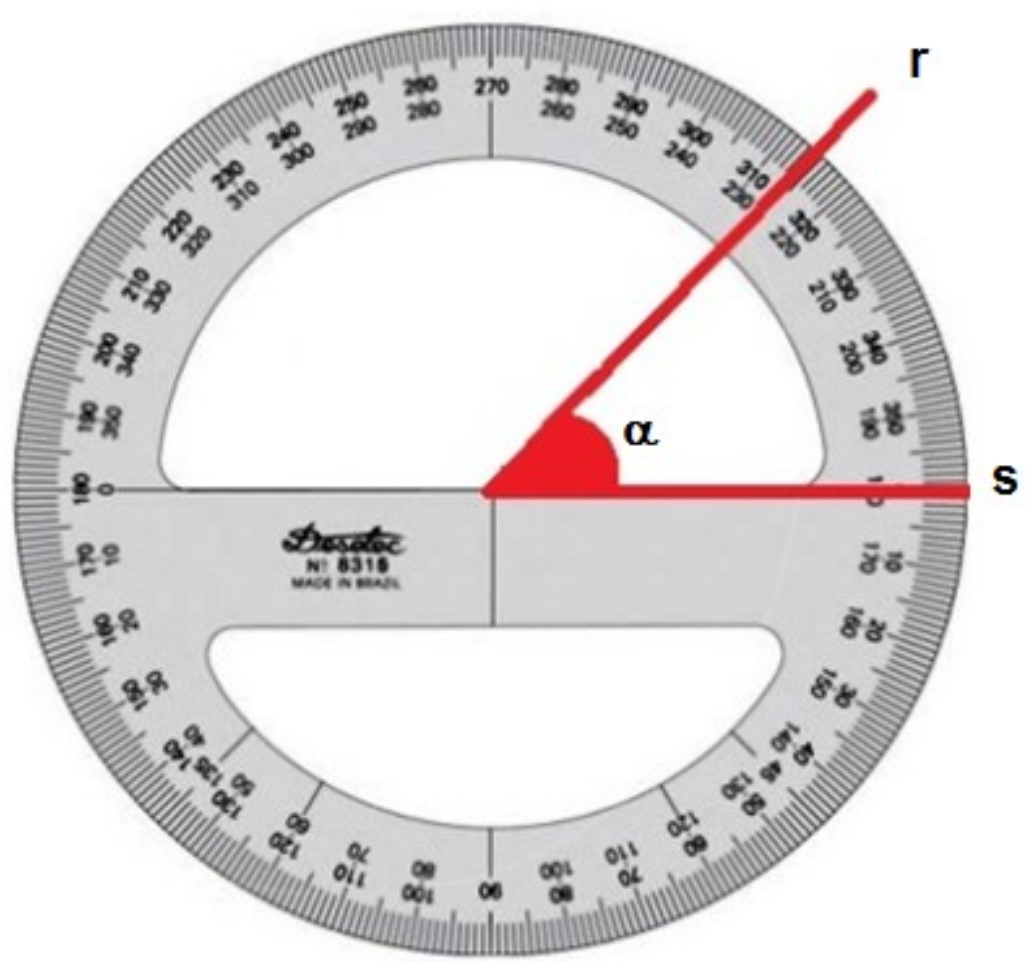

Figura 2.7 - As retas re s representam as leituras no Teodolito e o ângulo $\square \square$ apresentado na figura representa a variação angular.

Os alunos também mediram a distância entre o anteparo do Teodolito até a parede que seria usada para fazer os testes utilizando uma trena. Estes valores já seriam suficientes para calcular a altura da parede usada como teste, de forma indireta. Os cálculos envolvidos serão apresentados nas próximas seções do trabalho.

Os alunos fizeram vários testes de medidas em sala de aula, solicitaram bastante explicações e as dúvidas foram solucionadas. Este período de familiarização com o Teodolito e com sua utilização foi de cerca de duas aulas, que totalizaram 90 minutos.

\subsubsection{Atividade prática utilizando o Teodolito}

A aula seguinte foi destinada apenas para atividade prática usando o Teodolito, onde cada aluno usou seu próprio instrumento de trabalho. Foi proposta uma atividade fora da sala de aula, no caso o pátio da escola, onde os alunos 
estariam "livres" para, da melhor forma, obter o valor aproximado da altura do prédio da escola de forma indireta, com o uso do Teodolito. Para que a atividade fosse direcionada foi distribuído um roteiro de trabalho, conforme mostra a figura 2.8.

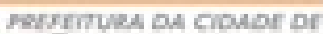

SÁO PAULO

Mome: I"

Serielano: Data:

TRABALHO-Prof José

Uso do Teodolito para medir ängulos em locais inacessiveis ou grandes distäncias

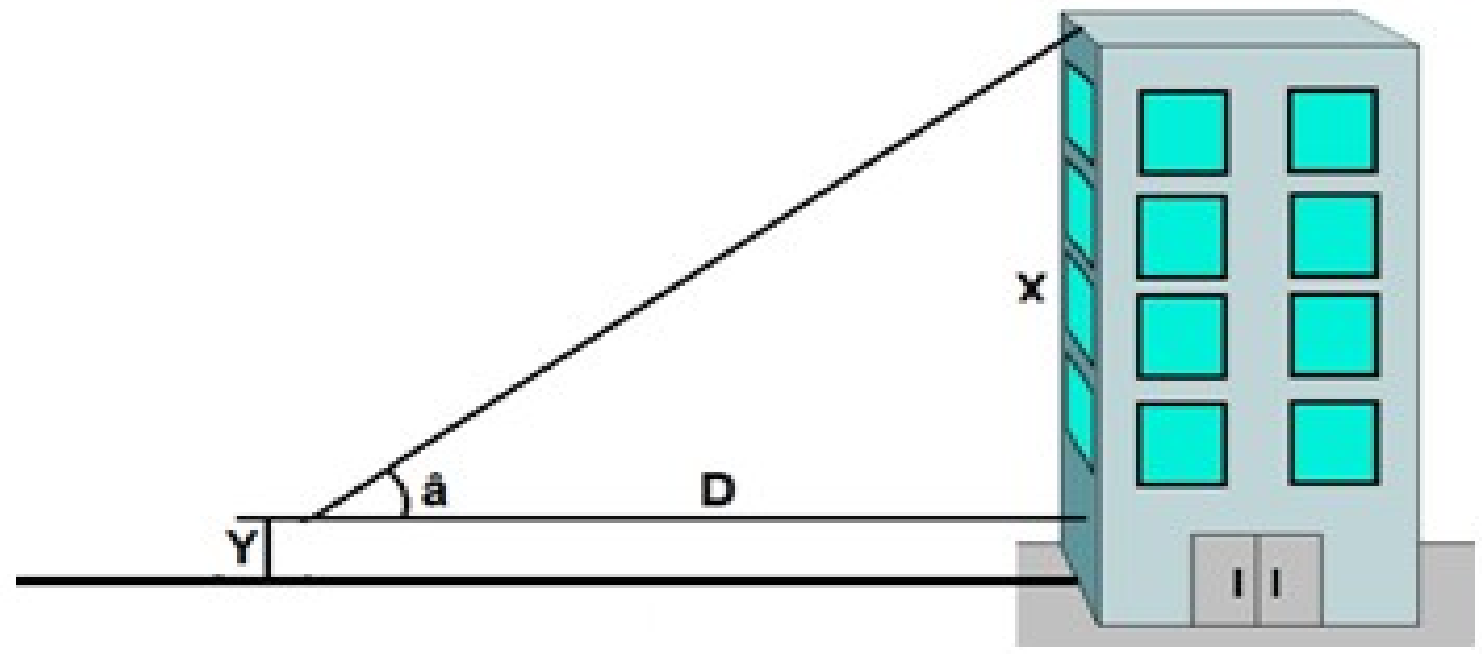

Escreva os valores medidos:

- Distancia entre o local da inedida do angulo e a base do predio (D) =

- Altura do Teodolito em relacio ao solo durante a medidado angulo $(\mathbf{W})=$

- Angulo Inedido pelo Teodolito (a) =

Cous trua um trîñ gulo apropriado (verso da fo lha) e utilize semelhang̣ de triângulas para calcular o valor de $\mathrm{K}$ da figura acima.

- Altura do Teodolito durante a inedida do ángulo atéo topo do predio $(\mathbf{0})=$

- Altura do predio $(\mathrm{X}+\mathrm{Y})=$

Figura 2.8 - Roteiro de atividade proposta para uso do Teodolito caseiro.

Foi enfatizado que os três primeiros campos a serem preenchidos (Distância entre o local da medida do ângulo e a base do prédio (D); Altura do Teodolito em 
relação ao solo durante a medida do ângulo (Y); Ângulo medido pelo Teodolito (â)) seriam obtidos apenas com utilização de instrumentos de medidas e que os outros dois campos (Altura do Teodolito durante a medida do ângulo até o topo do prédio $(\mathrm{X})$; Altura do prédio $(\mathrm{X}+\mathrm{Y})$ ), seriam obtidos através de cálculos e que poderiam ser realizados posteriormente.

Para que os alunos conseguissem determinar a distância do anteparo do Teodolito em relação à parede a ser analisada $(D)$ foram distribuídas trenas graduadas, bastante usadas em serviços de construção civil, o mesmo material de medida foi usado para verificar a altura do anteparo do Teodolito em relação ao solo (Y), cada aluno realizou as devidas marcações em seus roteiros. Os alunos usaram como anteparos para o Teodolito carteiras escolares, cadeiras ou bancos. $\mathrm{Na}$ parede que seria analisada cada aluno fez uma marcação na mesma altura em relação ao solo que o anteparo encontrava-se.

Por fim, era necessário obter o valor da variação angular entre a marcação da altura do anteparo projetada no muro da escola e o topo do muro. Neste momento o Teodolito foi usado para realizar as duas leituras necessárias, a primeira apontando o leitor do Teodolito para a marcação do anteparo projetada no muro e a segunda com o leitor do Teodolito apontando para o topo do muro. Após realizar a operação de subtração entre as duas leituras o valor correspondente à variação angular (â) foi anotado no roteiro do trabalho. Na figura 2.9 os alunos estão fazendo as devidas medidas e anotações em seus roteiros de trabalho. 

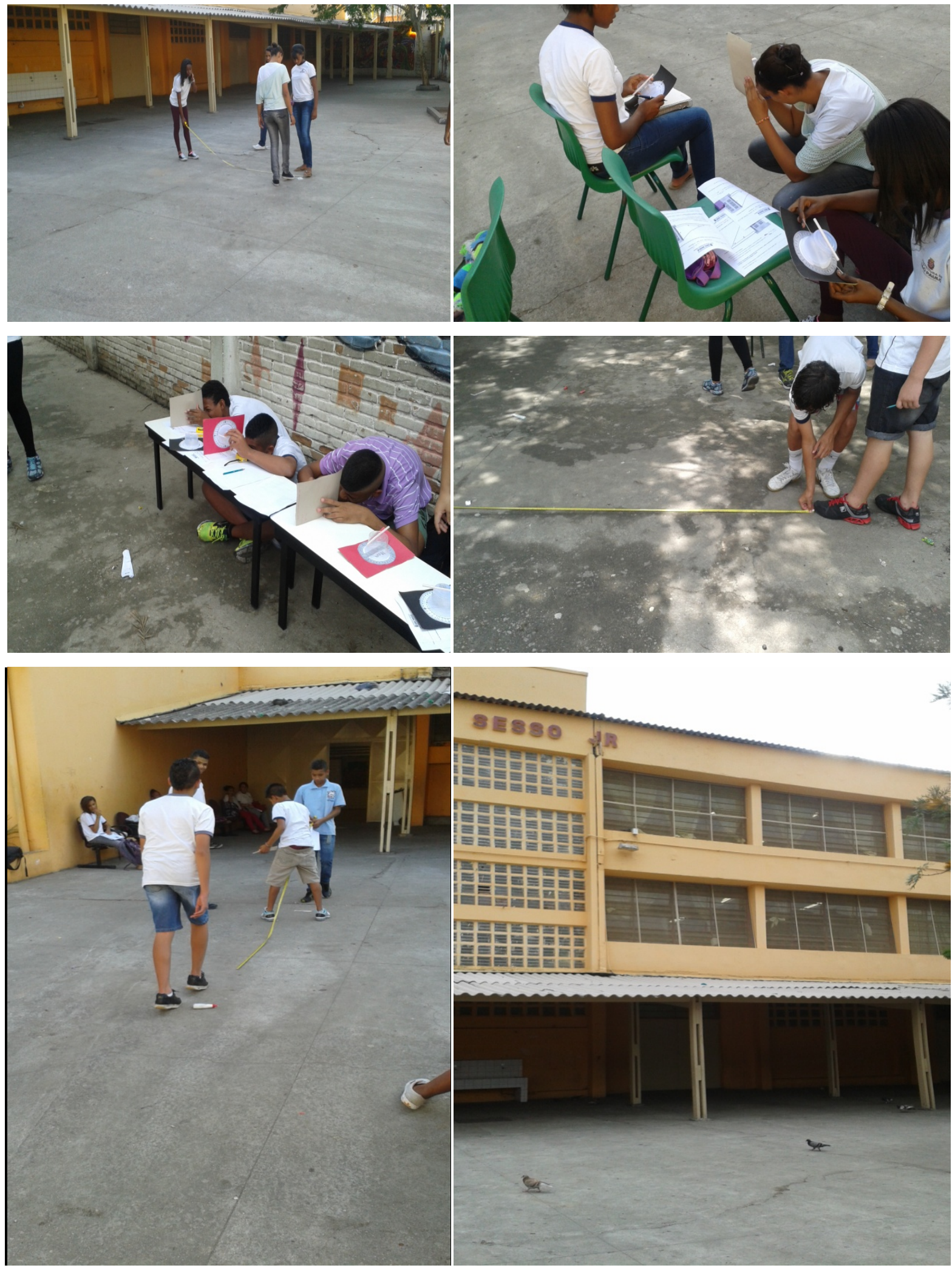

Figura 2.9 - Alunos realizando as medidas no pátio da escola, a última imagem é referente ao muro de altura desejada. 
Com essas medidas foi construído um triângulo retângulo imaginário onde um dos catetos era a distância entre o local da leitura feita com o uso do Teodolito e o muro de altura a ser calculada e o outro cateto a altura do muro a ser calculada, subtraída do valor da altura do anteparo usado pelo Teodolito, tendo dois ângulos conhecidos: um de valor $90^{\circ}$ (formado pela reta paralela ao solo e pela altura do muro do prédio da escola) e o outro ângulo de valor obtido com o uso do Teodolito.

\subsection{Cálculos utilizados para obtenção da medida da altura do prédio da escola}

Este trabalho foi aplicado em turmas do $8^{\circ}$ do ensino fundamental e nesta etapa escolar o conteúdo referente à trigonometria ainda não foi apresentado, pois não é conteúdo específico conforme prevê a grade curricular vigente (SÃO PAULO, 2010).

Foi usado o método de semelhança de triângulo, pois este assunto já havia sido trabalhado com estas turmas. No verso da folha referente ao roteiro do trabalho cada aluno desenhou um triângulo, usando régua e transferidor escolar. Para desenhar um triângulo semelhante ao do trabalho proposto era necessário apenas construir um triângulo que possuísse um dos ângulos com medida de $90^{\circ}$ e o outro com a medida obtida com o uso do Teodolito (â), neste caso o terceiro ângulo já está definido, pois a soma dos três ângulos de um triângulo é sempre igual a $180^{\circ}$.

Após a construção deste triângulo o aluno estava diante da seguinte situação problema:

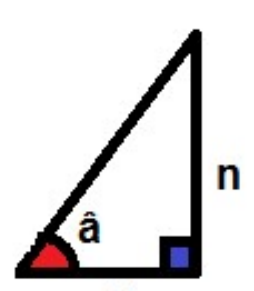

m

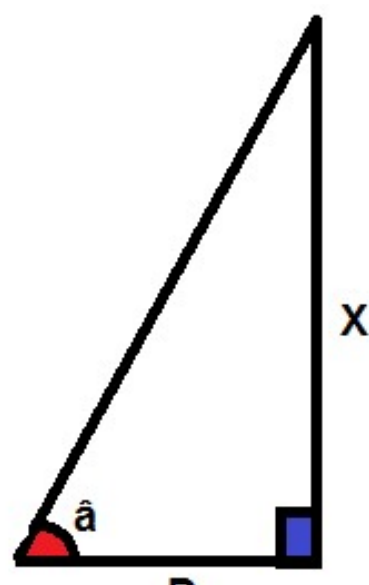

D

Figura 2.10 - Representação dos triângulos que foram usados pelos alunos. 
Na figura 2.10, o triângulo menor, do lado esquerdo, foi construído com o uso de transferidor e régua e o triângulo maior, do lado direito, é um triângulo imaginário construído usando as dimensões medidas no pátio da escola. O ângulo â tem o mesmo valor nos dois triângulos e ambos são triângulos retângulos, ou seja, são triângulos semelhantes (ANDRINI, 2012).

Após a construção do triângulo menor, cada aluno mediu e anotou o tamanho dos catetos do mesmo, desta forma, os valores $m$ e $n$ eram conhecidos e no triângulo maior a medida $D$ era conhecida, pois era o valor da distância entre o anteparo do Teodolito até o muro da escola medido por cada aluno. Era necessário que o aluno resolvesse a seguinte equação, sendo $X$ a única incógnita:

$$
\frac{m}{n}=\frac{D}{X} \rightarrow X=\frac{n \cdot D}{m}
$$

Como $X$, na ilustração do roteiro do trabalho, representava a distância entre a marcação da projeção da altura do anteparo do Teodolito ( $Y$ ) até o topo do muro da escola, então o valor da altura do muro da escola foi obtido realizando a soma:

$$
X+Y=\text { altura do muro da escola }
$$

\subsection{Cálculos realizados para comparação dos valores calculados com o esperado}

Os valores obtidos pelos alunos foram organizados em tabelas e para facilitar as devidas análises os mesmos foram divididos em faixas de frequência.

De acordo com Tavares (2011) inicialmente é necessário determinar o número de classes (k) em que os dados são agrupados. Esse cálculo depende da quantidade de valores $(n)$ :

$$
\begin{aligned}
& k=\sqrt{n}, \text { para } n \leq 100 \\
& k=5 \cdot \log n, \text { para } n>100
\end{aligned}
$$


Neste trabalho foi utilizada a equação 2.3 para obter o número de classe, pois a quantidade de alunos envolvidos foi inferior a 100. Deve-se ressaltar que o número de classe é um valor inteiro, sendo seu arredondamento realizado utilizando o padrão de algarismos significativos.

Além disso, é necessário determinar a amplitude de classe (c), que utiliza uma relação entre a amplitude total dos dados $(A)$, ou seja, a diferença entre o maior e o menor valor da amostra e o número de classe (k). Esta relação é definida por:

$$
c=\frac{A}{k-1}
$$

E, por fim, os limites inferior e superior de cada classe são obtidos considerando que o ponto médio da primeira classe é definido como o menor valor da amostra. Ou seja:

$$
\text { Limite inferior da } 1^{\mathrm{a}} \text { classe }=\text { menor valor }-\frac{c}{2}
$$

Para verificar se os valores obtidos a partir dos cálculos realizados pelos alunos foram compatíveis com o esperado optou-se em comparar o valor esperado com a média aritmética $(\bar{X})$ dos dados, considerando a dispersão dos valores, por intermédio do desvio padrão amostral $(S)$.

As relações referentes a este procedimento estão expostas a seguir:

$$
\begin{gathered}
\bar{x}=\frac{1}{n} \sum_{i=1}^{n}\left(x_{i}\right) \\
s=\sqrt{\frac{1}{n-1} \sum_{i=1}^{n}\left(x_{i}-\bar{x}\right)^{2}}
\end{gathered}
$$




\section{RESULTADOS}

Ao final do trabalho os alunos conseguiram obter os valores planejados, sendo uma parte através de medidas e outra parte utilizando cálculos. Desse modo, este capítulo está explicado em duas etapas.

\subsection{Valores obtidos através de medidas}

A aula prática de utilização do Teodolito foi realizada no pátio da escola, local cujo muro de altura a ser determinada estava localizado.

Durante as aulas teóricas os alunos já foram direcionados em relação de como deveriam ser realizadas as medidas para que conseguissem as informações necessárias para realização dos cálculos. Era esperado que ao final das medidas cada aluno possuísse os valores numéricos referentes aos seguintes campos do roteiro da atividade:

- Distância entre o local da medida do ângulo e a base do prédio (D);

- Altura do Teodolito em relação ao solo durante a medida do ângulo $(Y)$;

- Ângulo medido pelo Teodolito (â).

As figuras 3.1, 3.2 e 3.3 mostram os valores obtidos por três alunos usando os instrumentos de medidas, os campos obtidos através de cálculos também estão preenchidos, mas eles foram calculados posteriormente em sala de aula. 


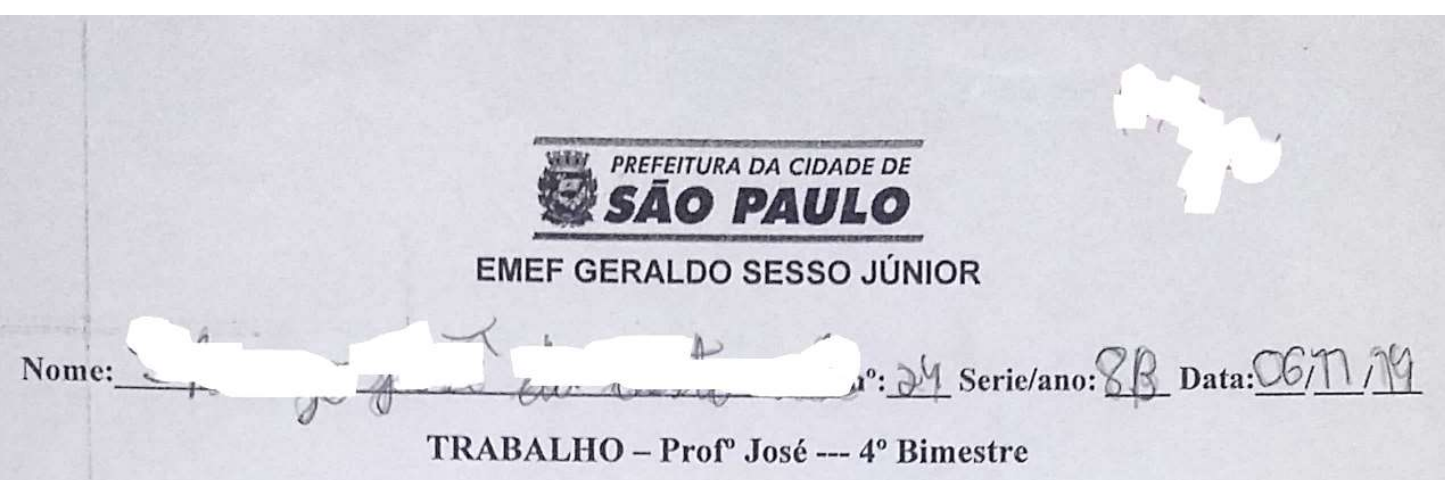

Uso do Teodolito para medir ângulos em locais inacessíveis ou grandes distâncias

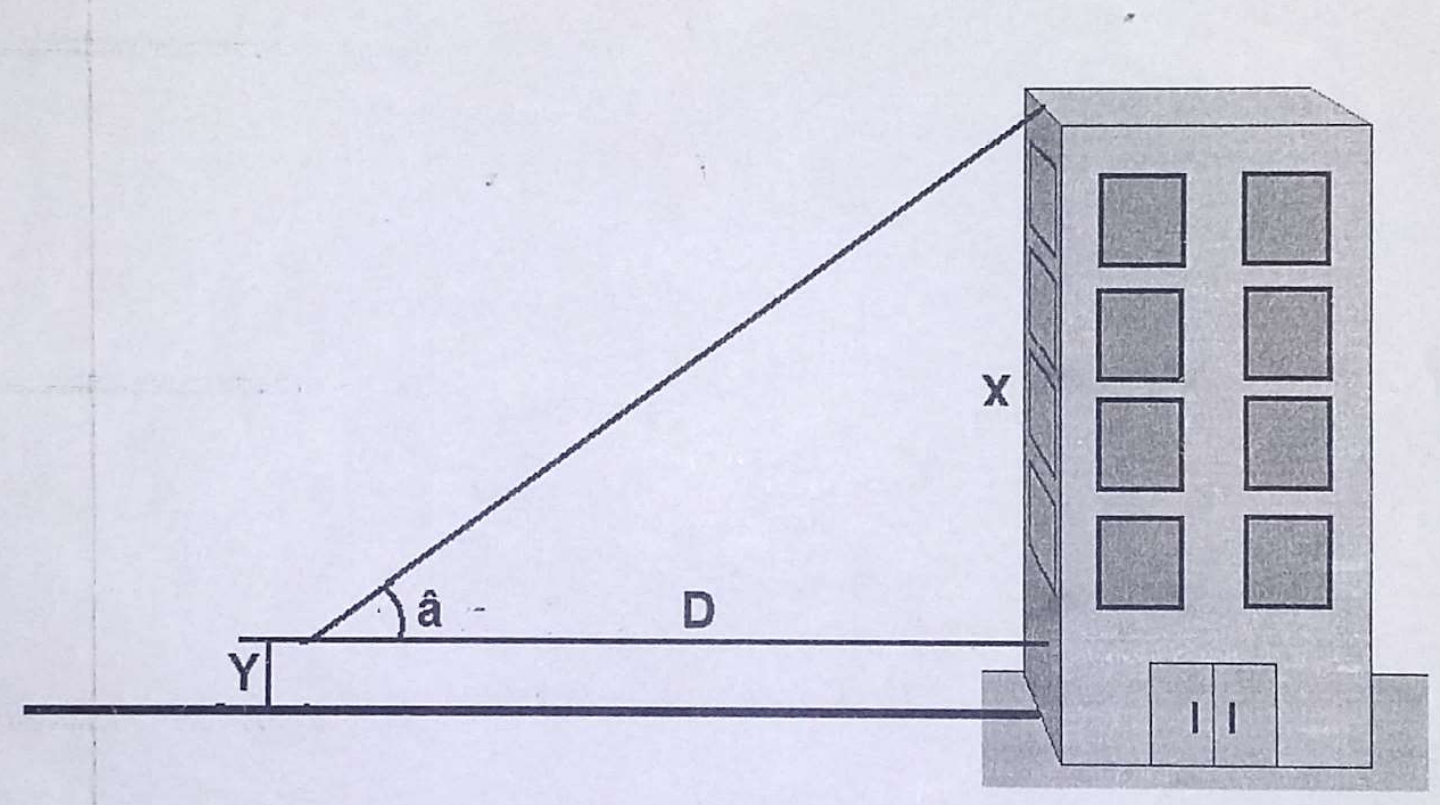

Escreva os valores medidos:

- Distância entre o local da medida do ângulo e a base do prédio (D) =

- Altura do Teodolito em relação ao solo durante a medida do ângulo $(\mathrm{Y})=$

- Ângulo medido pelo Teodolito $(\hat{\mathbf{a}})=$

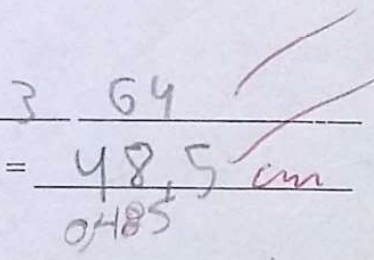

Construa um triângulo apropriado (verso da folha) e utilize semelhança de triângulos para calcular 0 valor de $\mathrm{X}$ da figura acima.

- Altura do Teodolito durante a medida do ângulo até o topo do prédio $(\mathbf{X})=$

- Altura do prédio $(\mathbf{X}+\mathbf{Y})=74,289 \mathrm{~m}$

Figura 3.1 - Valores obtidos utilizando os instrumentos de medidas. Aluno A. 


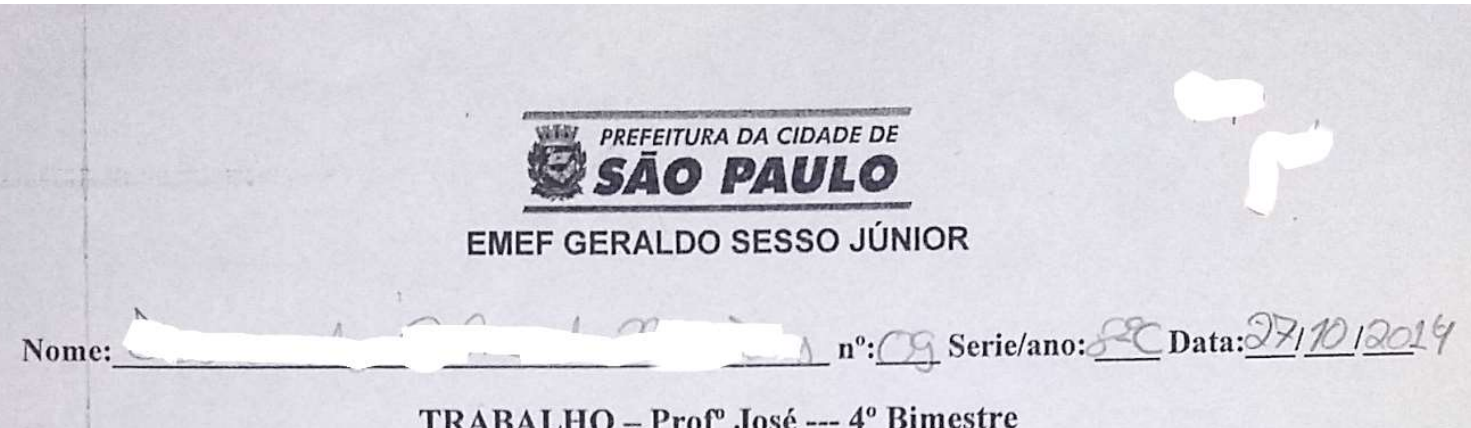

Uso do Teodolito para medir ângulos em locais inacessíveis ou grandes distâncias

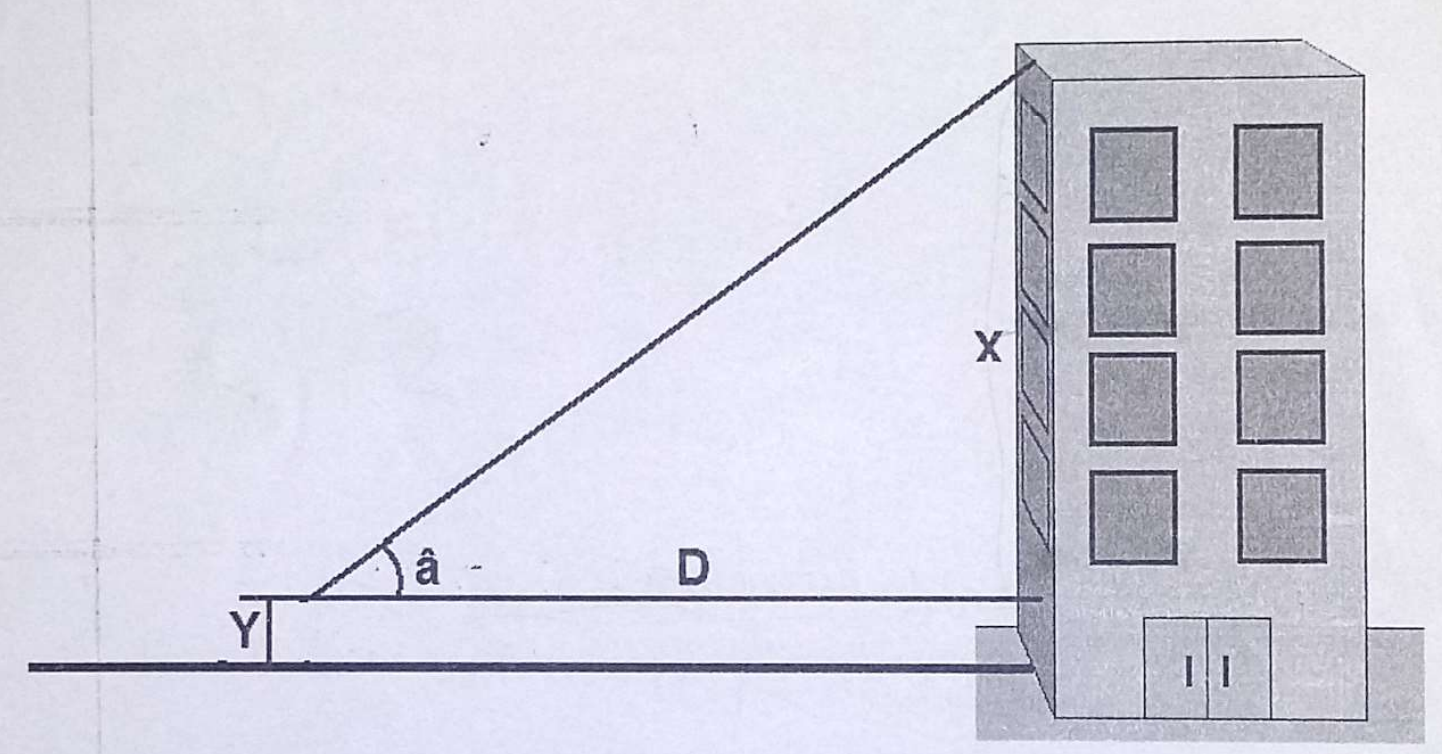

Escreva os valores medidos:

- Distância entre o local da medida do ângulo e a base do prédio (D) =

- Altura do Teodolito em relação ao solo durante a medida do ângulo (Y) =

- Ângulo medido pelo Teodolito $(\hat{a})=$
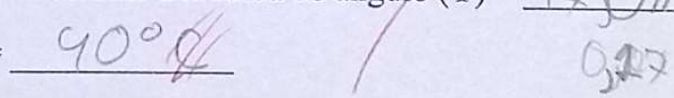

Construa um triângulo apropriado (verso da folha) e utilize semelhança de triângulos para calcular 0 valor de $\mathrm{X}$ da figura acima.

- Altura do Teodolito durante a medida do ângulo até o topo do prédio $(X)=12,83$ An

- Altura do prédio $(\mathbf{X}+\mathbf{Y})=$ $13,00 \mathrm{nn}$

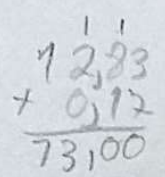

Figura 3.2 - Valores obtidos utilizando os instrumentos de medidas. Aluno B. 
EMEF GERALDO SESSO JÚNIOR

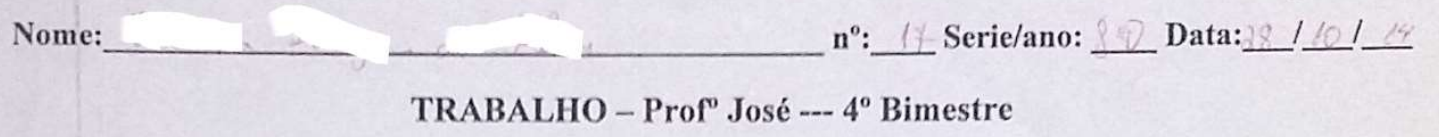

Uso do Teodolito para medir ângulos em locais inacessíveis ou grandes distâncias

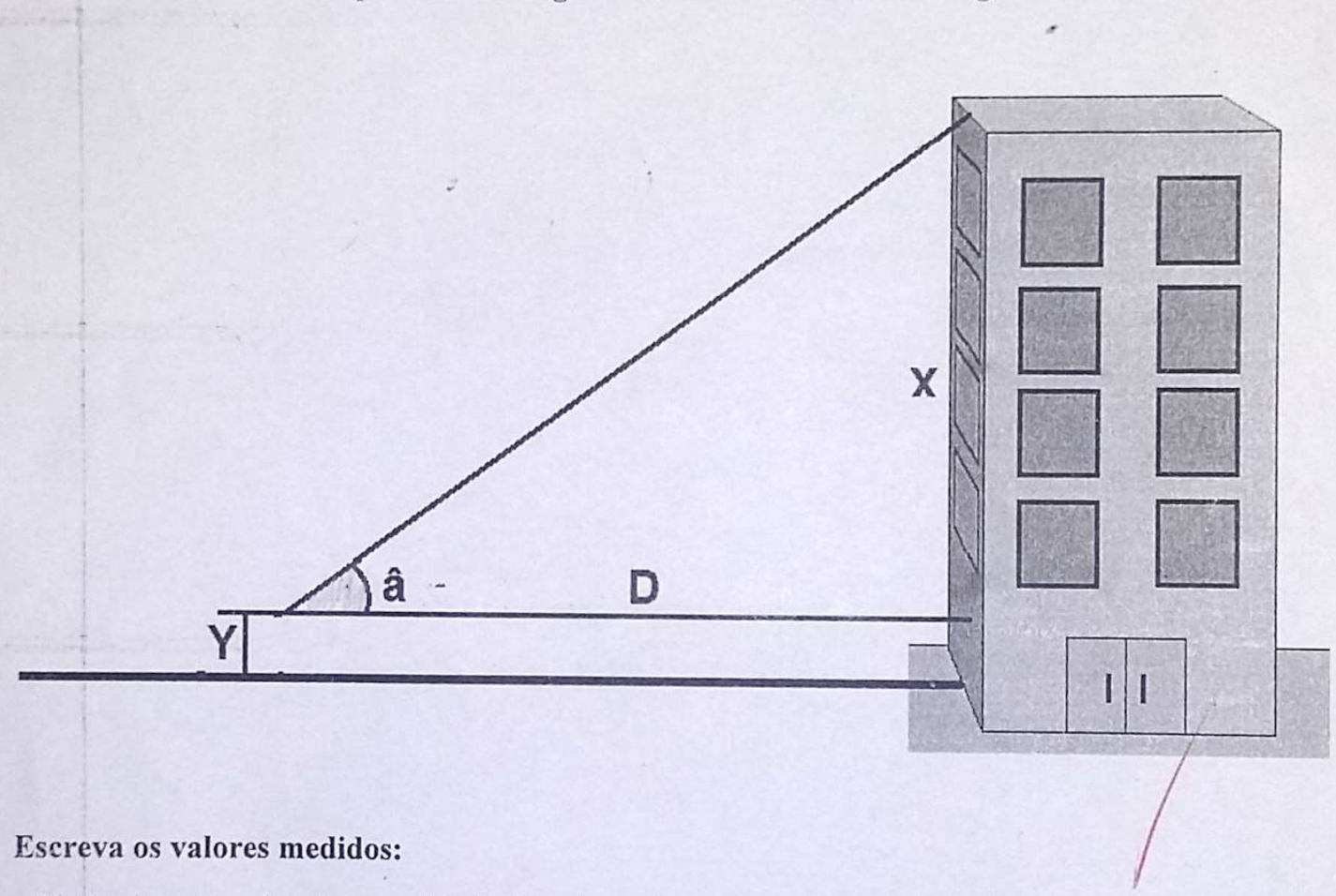

- Distância entre o local da medida do ângulo e a base do prédio (D) =

- Altura do Teodolito em relação ao solo durante a medida do ângulo (Y) =

- Ângulo medido pelo Teodolito (â)

Construa um triângulo apropriado (verso da folha) e utilize semelhança de triângulos para calcular o valor de $\mathrm{X}$ da figura acima.

- Altura do Teodolito durante a medida do ângulo até o topo do prédio $(X)=13,066 \mathrm{~m}$

- Altura do prédio $(X+Y)=14,566 m$

Figura 3.3 - Valores obtidos utilizando os instrumentos de medidas. Aluno C. 


\subsection{Valores obtidos através de cálculos}

$\mathrm{Na}$ aula seguinte, depois que os alunos realizaram as medidas, os mesmos foram orientados a desenhar triângulos utilizando um ângulo de $90^{\circ}$ e outro igual ao ângulo â medido. Dessa forma, este triângulo desenhado seria semelhante ao triângulo imaginário obtido pelas medidas coletadas.

Em seguida, cada aluno calculou o valor $X$ do roteiro (altura da posição do Teodolito durante a medida do ângulo até o topo do prédio) e somou com $\circ Y$, obtendo assim a altura do prédio.

As figuras $3.4,3.5$ e 3.6 mostram os cálculos desenvolvidos pelos mesmos 3 alunos das figuras 3.1, 3.2 e 3.3 : 


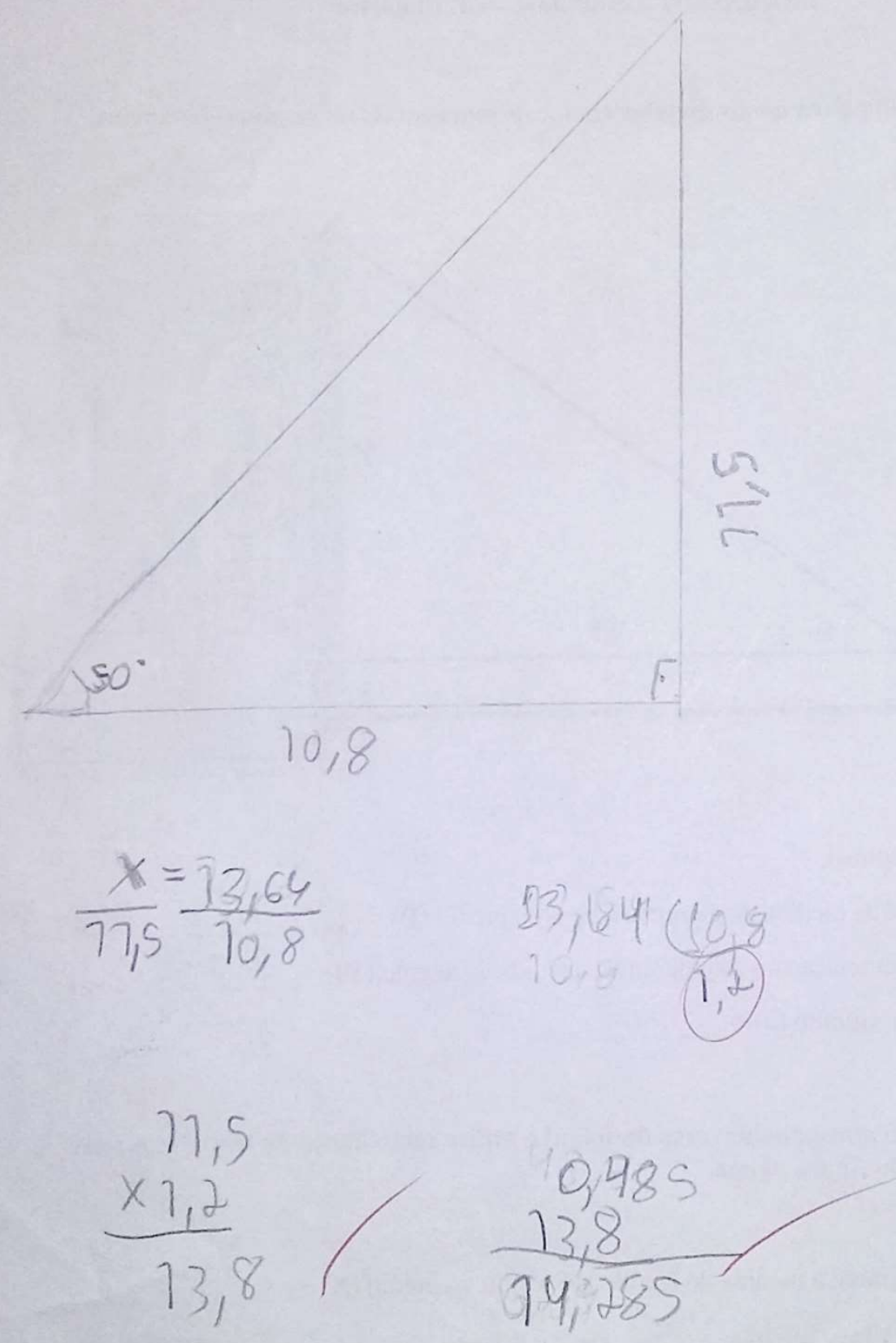

Figura 3.4 - Cálculos desenvolvidos para obter a altura do muro da escola. Aluno A. 

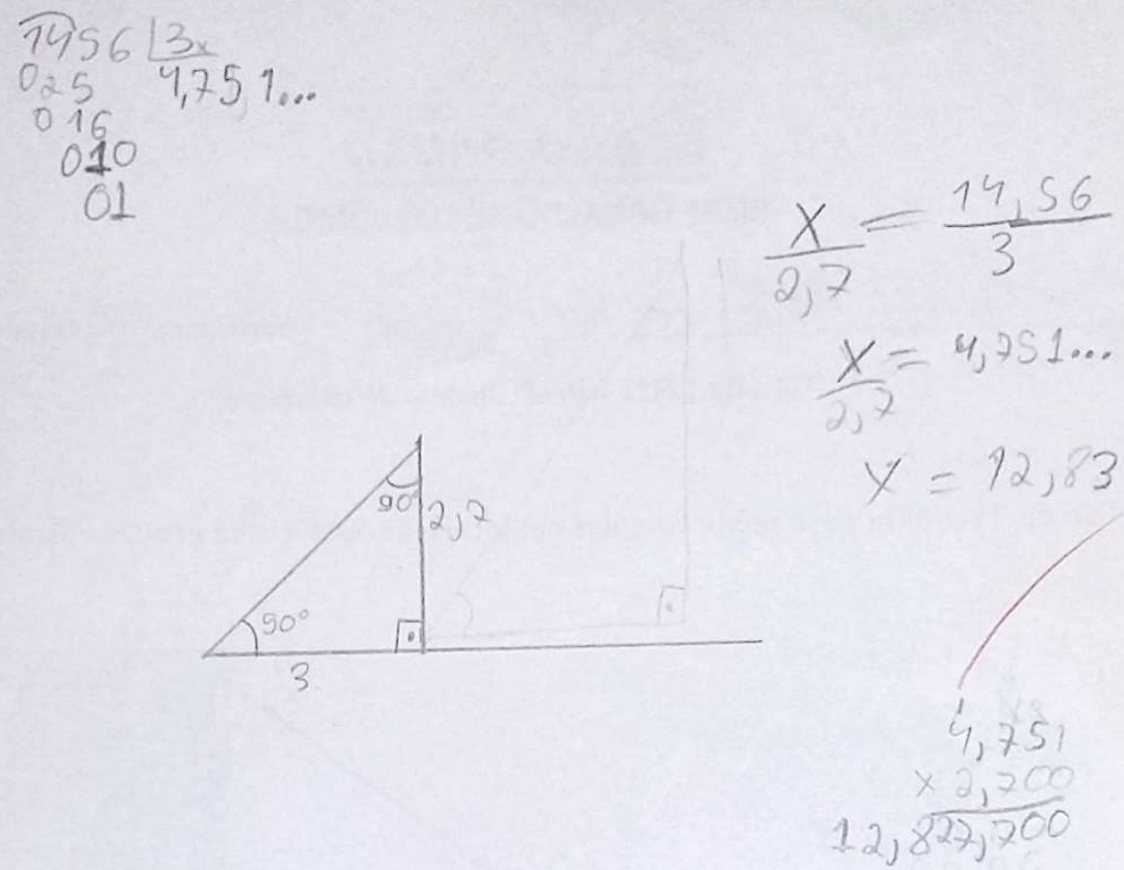

Figura 3.5 - Cálculos desenvolvidos para obter a altura do muro da escola. Aluno B. 


$$
\begin{aligned}
& \frac{x}{84}=\frac{13,90}{10}=\frac{x}{1.39} \\
& x=13.066
\end{aligned}
$$

Figura 3.6 - Cálculos desenvolvidos para obter a altura do muro da escola. Aluno C. 
Os valores da altura da parede calculados pelos alunos estão expostos na tabela 3.1, estes valores foram obtidos em metro, com aproximação em duas casas decimais. Por questão de organização os dados estão agrupados por turma.

Tabela 3.1 - Valores da altura obtidos pelos alunos, agrupados por turma.

\begin{tabular}{cccc}
\hline \multicolumn{4}{c}{ Altura da parede $\mathbf{( m )}$} \\
\hline $\mathbf{8}^{\mathbf{0}} \mathbf{A}$ & $\mathbf{8}^{\mathbf{0}} \mathbf{B}$ & $\mathbf{8}^{\mathbf{0}} \mathbf{C}$ & $\mathbf{8}^{\mathbf{0}} \mathbf{~}$ \\
\hline 8,18 & 13,60 & 11,89 & 14,57 \\
13,86 & 14,28 & 13,00 & 14,80 \\
8,11 & 24,28 & 12,42 & 21,42 \\
7,68 & 14,23 & 16,35 & 12,50 \\
12,63 & 10,01 & 15,15 & 11,17 \\
20,14 & 11,37 & 12,81 & 21,70 \\
12,20 & 7,84 & 11,31 & 18,11 \\
12,00 & 15,42 & 11,79 & 18,97 \\
12,75 & 13,23 & 10,66 & 14,44 \\
11,50 & 19,72 & 14,42 & 16,75 \\
13,61 & 15,48 & 11,07 & 11,12 \\
17,05 & 13,74 & 13,98 & 21,42 \\
12,30 & 12,46 & & 11,70 \\
12,03 & & & 19,75 \\
& & &
\end{tabular}

Utilizando as equações $2.3,2.5$ e 2.6 obteve-se as informações para organização dos dados em forma de distribuição de frequência:

Tabela 3.2 - Dados calculados para facilitar a distribuição de frequência.

\begin{tabular}{cccccc}
\hline \multicolumn{5}{c}{ Dados para distribuição de frequência } \\
\hline & $\mathbf{8}^{\circ} \mathbf{A}$ & $\mathbf{8}^{\circ} \mathbf{B}$ & $\mathbf{8}^{\circ} \mathbf{C}$ & $\mathbf{8}^{\circ} \mathbf{~}$ \\
\hline $\mathbf{N}^{\circ}$ dados (n) & 14 & 13 & 12 & 14 \\
$\mathbf{N}^{\circ}$ de classe (k) & 3,74 & 3,61 & 3,46 & 3,74 \\
Amplitude total (A) (em metros) & 12,46 & 16,44 & 5,69 & 10,58 \\
& & & & \\
Amplitude de classe (c) (em metros) & 4,54 & 6,31 & 2,31 & 3,86 \\
& & & & \\
\hline
\end{tabular}


Desta forma, os dados foram distribuídos em frequências, como pode ser visualizado na tabela 3.3.

Tabela 3.3 - Valores agrupados por turma, expostos em distribuição de frequência.

\begin{tabular}{|c|c|c|c|c|c|c|c|}
\hline \multicolumn{8}{|c|}{ Distribuição de frequência } \\
\hline \multicolumn{2}{|l|}{$8^{\circ} \mathrm{A}$} & \multicolumn{2}{|l|}{$8^{\circ} \mathrm{B}$} & \multicolumn{2}{|l|}{$8^{\circ} \mathrm{C}$} & \multicolumn{2}{|l|}{$8^{\circ} \mathrm{D}$} \\
\hline Altura (m) & Freq. & Altura (m) & Freq. & Altura (m) & Freq. & Altura (m) & Freq. \\
\hline $5,41-9,95$ & 3 & $4,69-10,99$ & 2 & $9,51-11,81$ & 4 & $9,19-13,05$ & 4 \\
\hline $9,95-14,50$ & 9 & $10,99-17,30$ & 9 & $11,81-14,12$ & 5 & $13,05-16,91$ & 4 \\
\hline $14,50-19,04$ & 1 & $17,30-23,61$ & 1 & $14,12-16,43$ & 3 & $16,91-20,77$ & 3 \\
\hline $19,04-23,59$ & 1 & $23,61-29,92$ & 1 & & & $20,77-24,63$ & 3 \\
\hline
\end{tabular}

Com os valores agrupados da forma que estão apresentados na tabela 3.3 foi possível representá-los em forma de histograma. Esta visualização está exposta nas figuras $3.7,3.8,3.9$ e 3.10 .

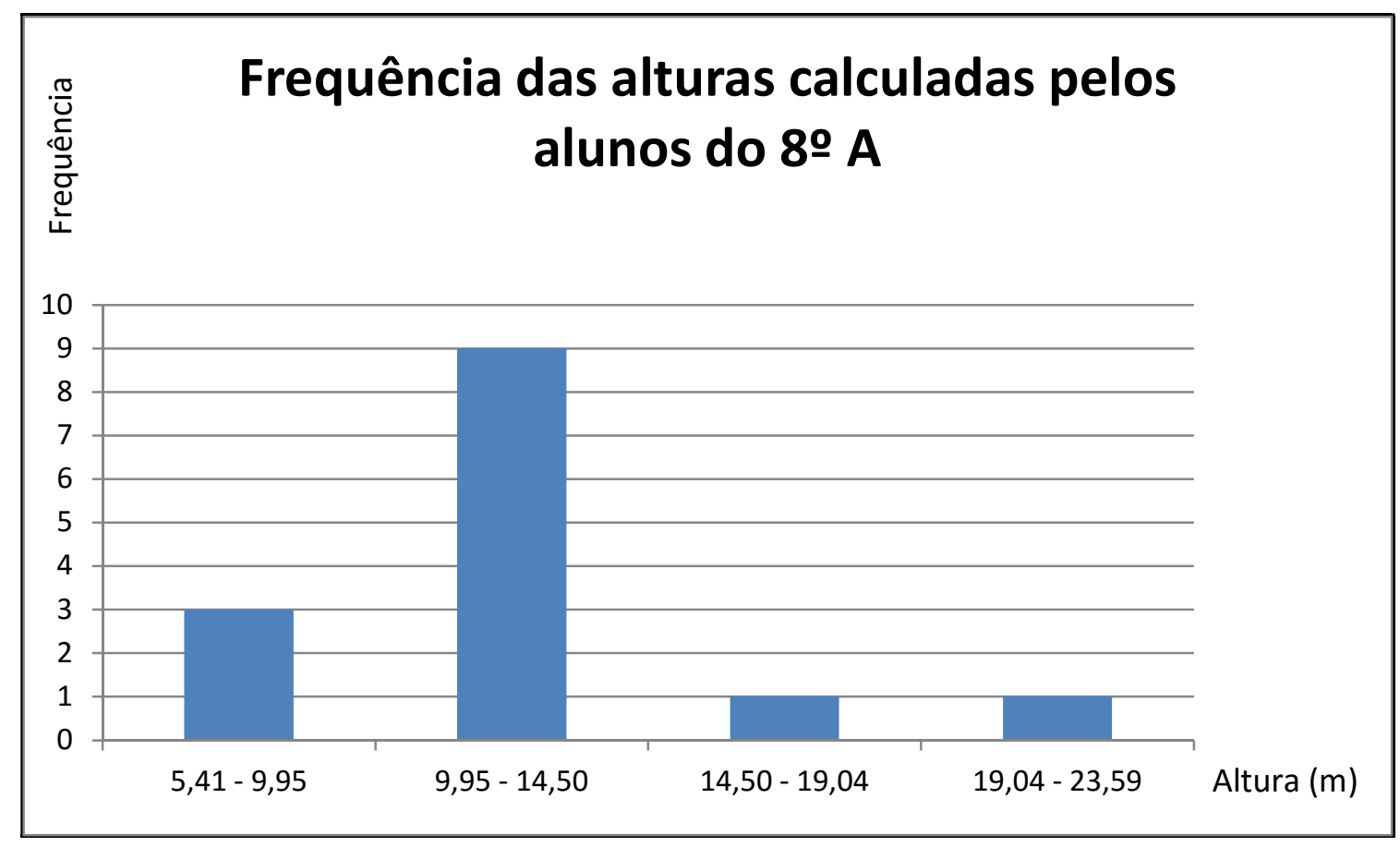

Figura 3.7 - Histograma representando os valores calculados pelos alunos do $8^{\circ} \mathrm{A}$. 


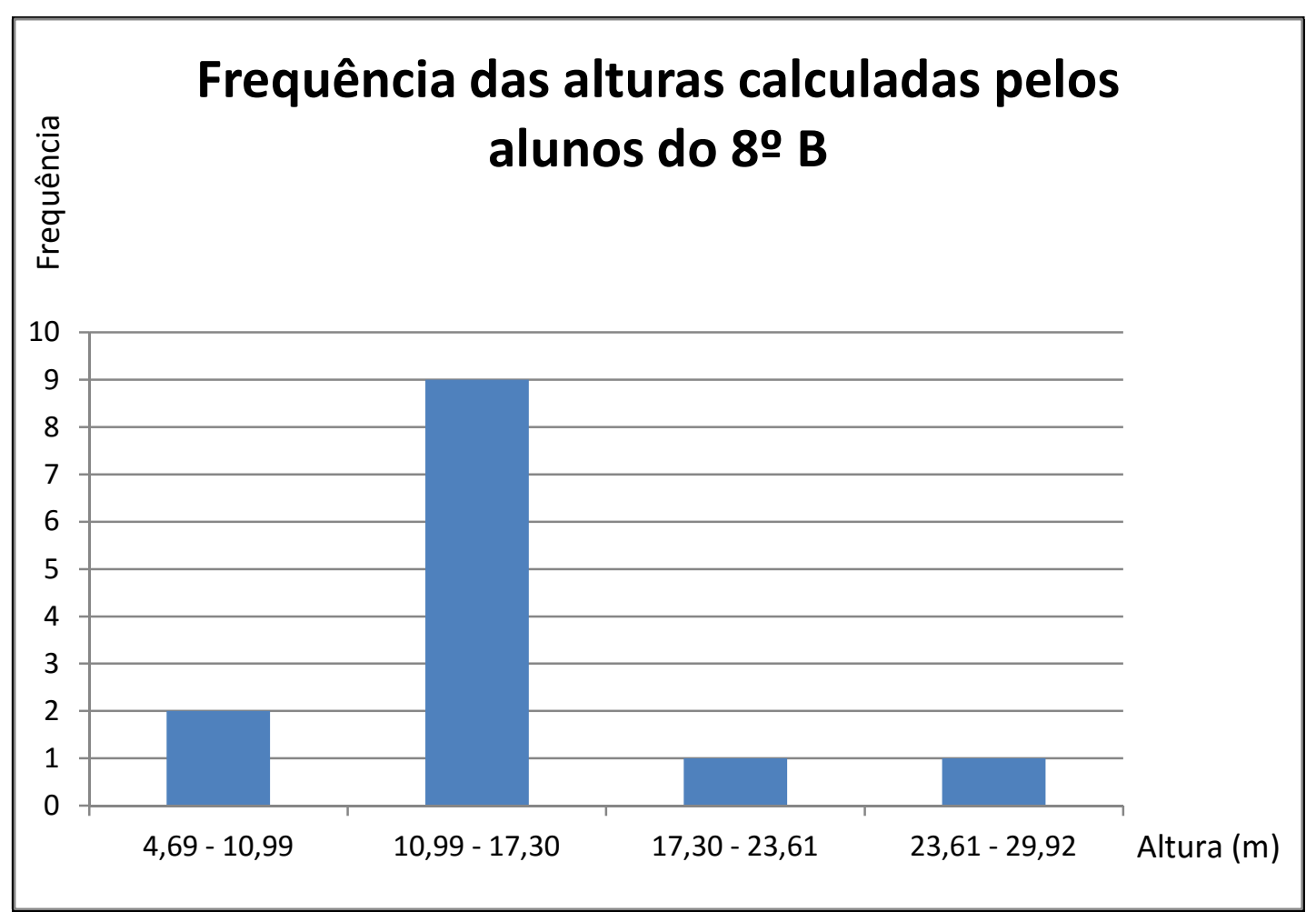

Figura 3.8 - Histograma representando os valores calculados pelos alunos do $8^{\circ} \mathrm{B}$.

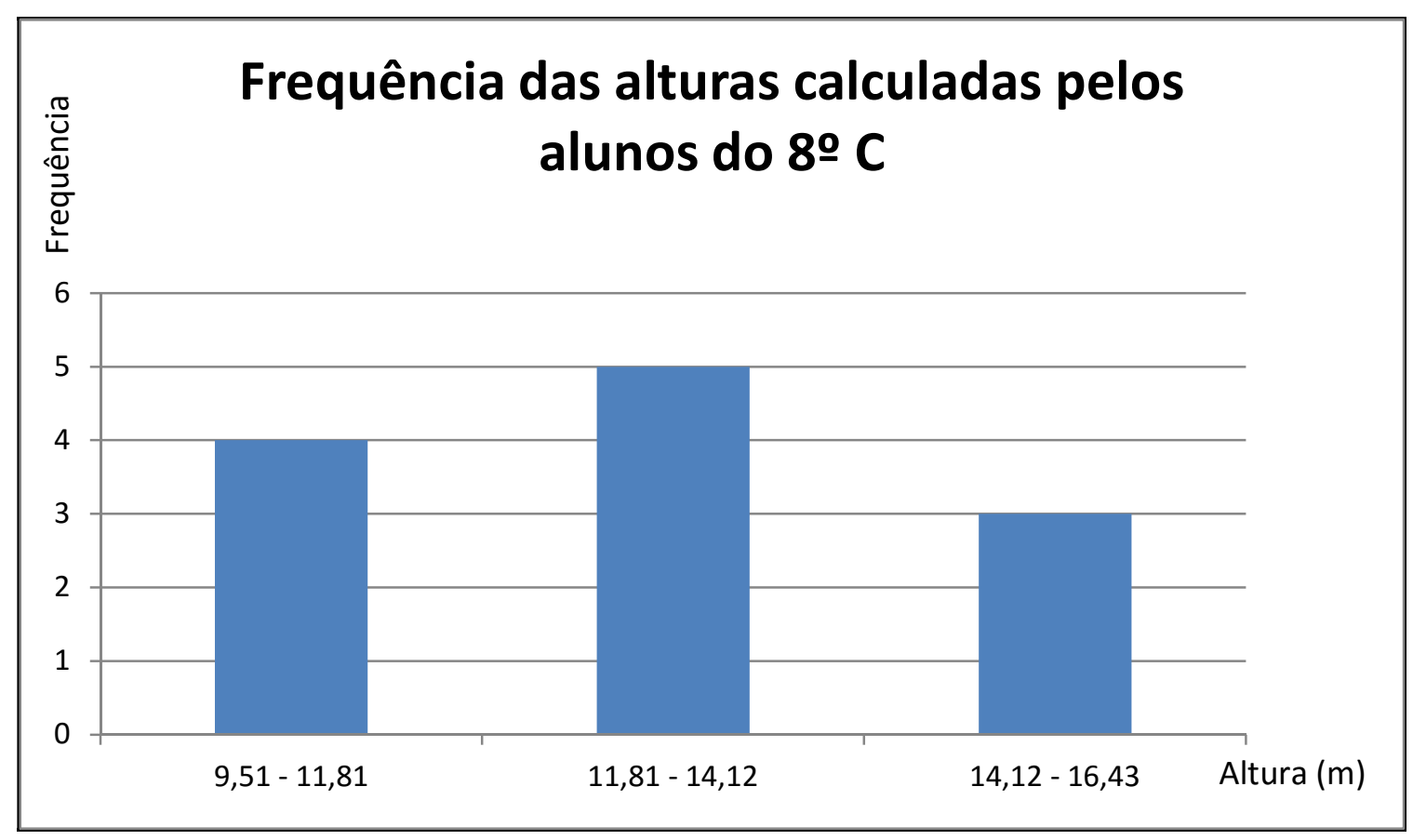

Figura 3.9 - Histograma representando os valores calculados pelos alunos do $8^{\circ} \mathrm{C}$. 


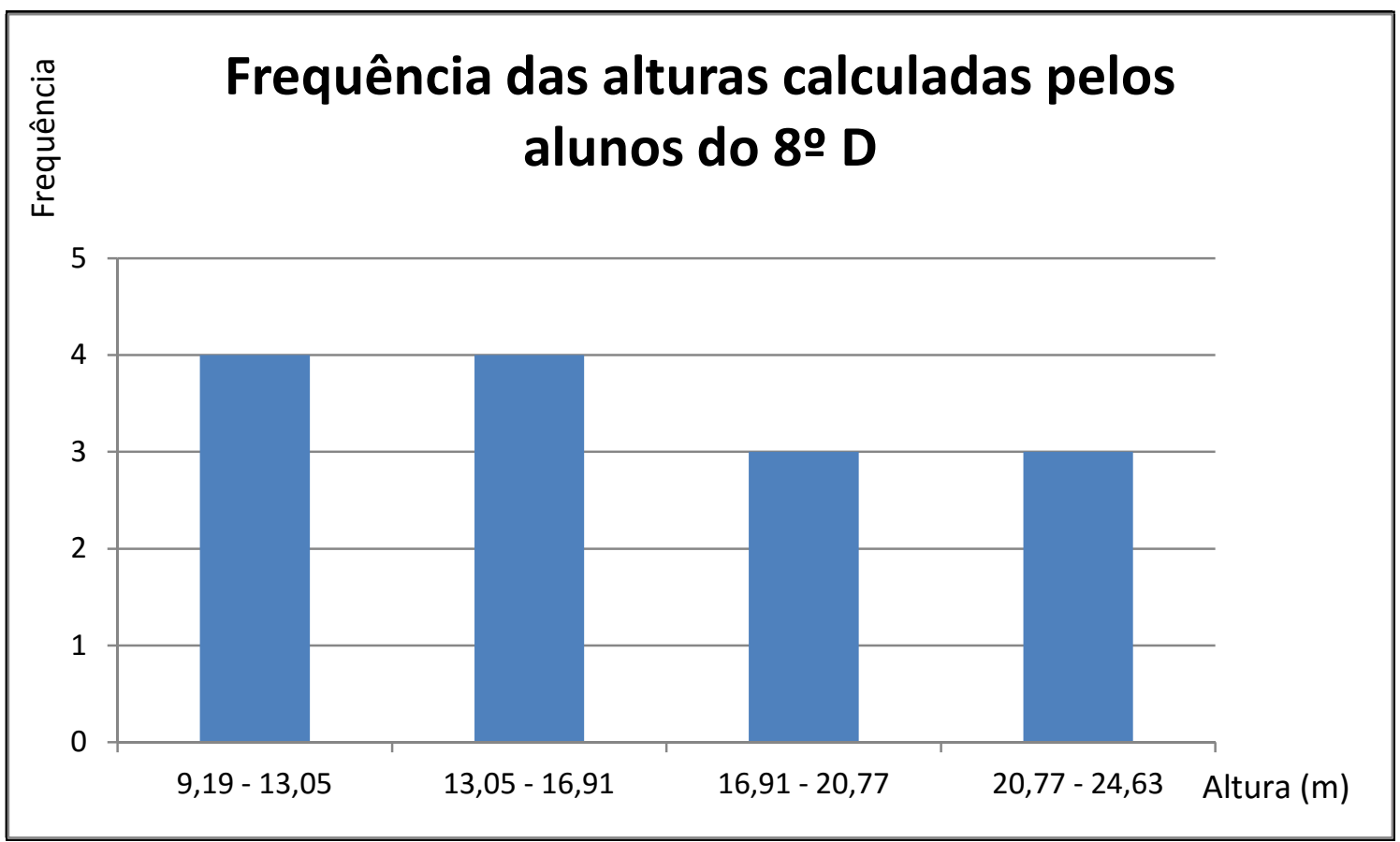

Figura 3.10 - Histograma representando os valores calculados pelos alunos do $8^{\circ} \mathrm{D}$.

Além disso, com o uso das equações 2.7 e 2.8 foi calculada a média da altura obtida pelos alunos de cada turma, resultando nos valores da tabela 3.4:

Tabela 3.4 - Altura média obtida por cada turma.

\begin{tabular}{cccc}
\hline \multicolumn{4}{c}{ Altura média da parede $(\mathbf{m})$} \\
\hline & & & \\
$\mathbf{8}^{\circ} \mathbf{A}$ & $\mathbf{8}^{\circ} \mathbf{B}$ & $\mathbf{8}^{\circ} \mathbf{C}$ & $\mathbf{8}^{\circ} \mathbf{~}$ \\
$12,43 \pm 3,34$ & $14,28 \pm 4,14$ & $12,90 \pm 1,75$ & $16,32 \pm 3,94$ \\
\hline
\end{tabular}

Por fim, estes dados foram agrupados e organizados em apenas um grupo de distribuição de frequência, sendo antes calculados os valores necessários: 
Tabela 3.5 - Dados calculados para facilitar a distribuição de frequência, utilizando todos valores agrupados.

\begin{tabular}{cc}
\hline \multicolumn{2}{c}{ Dados para distribuição de frequência } \\
\hline$N^{\circ}$ dados (n) & 53 \\
No $^{\circ}$ de classe (k) & 7,28 \\
Amplitude total (A) (em metro) & 16,6 \\
Amplitude de classe (c) (em metro) & 2,64 \\
\hline
\end{tabular}

Com esses valores foi calculada a distribuição de frequência:

Tabela 3.6 - Valores agrupados, expostos em distribuição de frequência.

\begin{tabular}{cc}
\hline \multicolumn{2}{c}{ Distribuição de frequência } \\
\hline Altura (m) & Freq. \\
$6,36-9,00$ & 4 \\
$9,00-11,64$ & 8 \\
$11,64-14,29$ & 22 \\
$14,29-16,93$ & 9 \\
$16,93-19,57$ & 3 \\
$19,57-22,22$ & 6 \\
$22,22-24,86$ & 1 \\
\hline
\end{tabular}

Para facilitar a visualização estes valores estão representados em forma de histograma na figura 3.11 : 


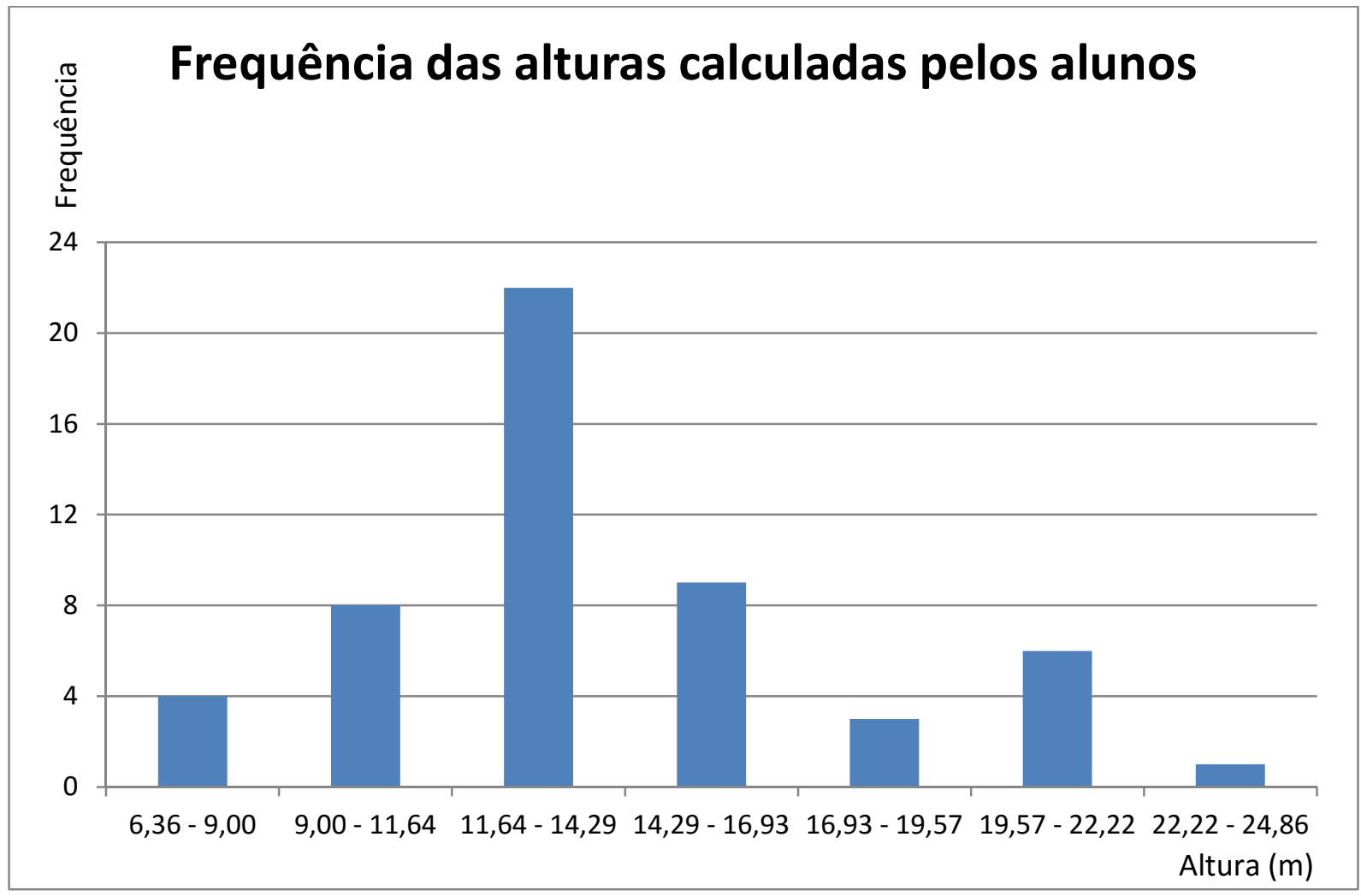

Figura 3.11 - Histograma representando os valores calculados de todos alunos.

E novamente com o uso das equações 2.7 e 2.8 foi calculada a média da altura obtida por todos alunos, resultando em 13,98 $\pm 3,67$ metros. 


\section{ANÁLISE E DISCUSSÃO DOS RESULTADOS}

As turmas que realizaram o trabalho de construção do Teodolito caseiro foram acompanhadas em todas as etapas do processo pelo professor, que buscou solucionar as eventuais dúvidas apresentadas pelos alunos, ao mesmo tempo em que também foi necessário recapitular alguns conteúdos para que o grupo de alunos pudesse acompanhar o assunto trabalhado.

$\mathrm{Na}$ realização da atividade os alunos puderam construir o seu próprio trabalho, fazendo as medições e sanando suas dúvidas pontualmente na prática. Outro ponto importante que pode ser observado é que a atividade exigiu dos alunos pequenos agrupamentos, o que os sensibilizou para que um procurasse a ajuda do outro, reforçando aspectos positivos como a interação, o cooperativismo, a organização, entre outros.

Observando os valores expostas na figura $3.7 \mathrm{em}$ forma de histograma foi possível verificar que a maioria dos alunos da turma do $8^{\circ} \mathrm{A}$ calcularam valores entre 9,95 e 14,50 metros, sendo que a média calculada foi $12,43 \pm 3,34$ metros. Os gestores da Unidade Escolar informaram que, de acordo com a documentação do prédio, a altura da parede tinha cerca de 12,00 metros. Dois valores apresentaram mais de 17,00 metros. Neste caso, como os cálculos foram verificados e revistos, imagina-se que esta discrepância deve-se a falta de prática no manuseio dos instrumentos de medidas, em especial o Teodolito, pois uma pequena falha na obtenção do ângulo pode resultar em um resultado maior na mensuração da altura do objeto analisado.

$\mathrm{Na}$ figura 3.8 foram expostos em forma de histograma os valores calculados pelos alunos do $8^{\circ} \mathrm{B}$. Nesta turma a maioria dos alunos obteve valores entre 10,99 e 17,30 metros, sendo que a média calculada foi $14,28 \pm 4,14$ metros. Como os alunos realizam as atividades coletivamente é possivel que tenha ocorrido algum erro sistemático no uso de um dos instrumentos de medidas. Há dois valores acima de 19,00 metros, neste caso é possível que tenha ocorrido erro na leitura dos ângulos usando o Teodolito.

Os valores calculados pelos alunos do $8^{\circ} \mathrm{C}$ estão expostos na figura $3.9 \mathrm{em}$ forma de histograma. Esta turma apresentou a maioria dos valores entre 11,81 e 
14,12 metros e como foi possível observar não apresentaram valores tão discrepantes da media 12,90 $\pm 1,75$ metros.

A quarta turma, $8^{\circ} \mathrm{D}$, apresentou os valores expostos em forma de histograma na figura 3.10. Verifica-se que os valores ficaram bem dispersos em todas as classes do intervalo, elevando a média para 16,32 $\pm 3,94$ metros. Acreditase que nesta turma também ocorreu algum erro sistemático na leitura do instrumento de medida ou mesmo na fabricação do Teodolito.

Ao analisar os dados como um todo verificou-se que a média do grupo ficou um pouco acima do esperado, 13,98 \pm 3,67 metros, mas compatível, considerando o desvio padrão amostral. Em contrapartida, ao observar o histograma representado na figura 3.11 verificou-se que a maioria dos valores estava disposta no intervalo entre 11,64 e 14,29 metros, ou seja, grande parte dos alunos conseguiu obter valores próximos do esperado. Os estudantes puderam observar que, mesmo sendo um método caseiro de mensuração de dados, é uma técnica que funciona quando aplicamos corretamente os cálculos matemáticos sobre 0 trabalho. Essa constatação para eles foi muito relevante, pois possibilitou que os estudantes pudessem verificar como a Matemática é importante em nosso dia-a-dia e como ela pode ser aplicada em termos práticos do cotidiano. 


\section{CONCLUSÕES}

Estamos acostumados a ouvir "para que" eu preciso estudar Matemática. Um fator determinante que objetivou a realização deste trabalho é mostrar "por que" podemos estudar Matemática, disciplina essa considerada muitas vezes abstrata e difícil de ser apreendida. Vimos como ela pode ser aplicada de várias formas, principalmente usando questões que estão muito próximas à realidade dos estudantes.

Essa relação da Matemática com o cotidiano exigiu dos alunos conhecimento de conceitos matemáticos, como a geometria, a álgebra, entre outros. A experiência proposta buscou trazer a Matemática para perto dos alunos, fazendo que seus conceitos pudessem ser aplicados em termos práticos, o que permite uma relação diferente dos alunos com os números.

Poderíamos discorrer sobre vários pontos importantes da Matemática em nossas vidas, como o desenvolvimento do raciocínio lógico, concentração, entre tantos outros pontos. Tudo isso parece ser muito simples, mas não é, se pensarmos que nos dias de hoje as pessoas sofrem de falta de atenção, usam as máquinas para quase tudo, pouco refletem sobre os seus processos de vida, porque alguém faz por elas. A Matemática, portanto, auxilia vários aspectos cognitivos do nosso cérebro que, em conjunto com outras atividades, amplia e desenvolve nossas capacidades físico-mentais.

A escola é um lugar propício para o saber e aprender, e o professor tem nas mãos uma grande responsabilidade com aqueles que ali estão sob sua orientação. Nesse sentido, os alunos esperam que o professor possa Ihes apresentar algum tipo de conhecimento que vá servir a eles na vida afora. Por isso, pensar nesse papel da escola e do professor na vida dos alunos sem mensurar a necessidade prática do conhecimento é uma atividade "muda e irresponsável", porque não dialoga com ninguém, não eleva o aluno de sua zona de conhecimento para transpor a uma outra zona de raciocínio.

Em "Dez Novas Competências para Ensinar", Perrenoud (2000) discorre sobre as práticas mais emergentes sobre a tarefa de ensinar e aprender. Muito mais de respostas, aponta caminhos: quais características espera-se para a educação do futuro? Sabemos que a educação vem se transformando e não é de hoje. Exige do 
professor um compromisso muito grande. Porém é uma atividade grandiosa e valiosa.

A experiência da construção do Teodolito trouxe uma nova expectativa sobre os alunos, pois após a realização da atividade os alunos sentiram-se mais motivados para futuros trabalhos, curiosos por outras questões no qual eles próprios pudessem ser os construtores de seu aprendizado, e não depositários de um conhecimento insosso, falido e diluído em aulas monótonas e repetitivas.

Durante a construção do Teodolito foi possível observar outros aspectos positivos entre a turma, como: espírito de cooperação, integração, diálogo, entre outros. Os alunos ficaram responsáveis por realizar todas etapas do processo de construção do Teodolito, onde foi possível observar que as habilidades são díspares, porém quando colocadas a serviço do coletivo concretizam-se em um trabalho bem elaborado.

Com relação à disposição dos recursos didáticos houve uma grande troca no sentido de que os alunos trouxeram seus materiais e aqueles que não trouxeram puderam contar com a colaboração dos colegas. A disposição das mesas na sala de aula formando pequenos grupos também foi outro ponto que procurou provocar os alunos didaticamente, ou seja, em pequenos grupos de quatro ou cinco estudantes os alunos puderam estar em contato mais uns com os outros e trocar ideias e informações entre si para realização da atividade.

A parte prática deste experimento teve como resultado esperado a participação de todos os alunos: cada um pode coletar as medidas que serviram de base para os cálculos e análise dos dados, e cada um pode sentir qual foi sua maior facilidade ou dificuldade durante a realização da construção do Teodolito.

Nos resultados, já havia a expectativa de que cada grupo de alunos chegasse a resultados diferentes, uma vez que o pouco contato com o instrumento e a falta de experiência com os instrumentos de medidas não permitia a precisão dos dados que eram esperados para ser obtidos. Mesmo assim, grande parte dos estudantes chegou a valores bem próximos do esperado, ou seja, mesmo sem a precisão nos resultados, os alunos chegaram a valores que podem ser classificados como satisfatórios.

Após a realização do trabalho de campo os alunos reafirmaram a atividade como positiva e satisfatória para suas vidas, pois enriqueceu seus conhecimentos pessoais e mostrou que a Matemática pode ser aplicada, sem que para isso seja 
necessariamente algo abstrato ou pouco acessível. A constatação dos alunos foi importante porque reforçou, mais uma vez o que já foi dito, ou seja, o conhecimento matemático pode ser aplicado sob várias formas, basta que os processos de ensino e aprendizagem debrucem-se sobre as necessidades e os interesses dos alunos, ou seja, esteja a serviço do aprendizado, e não ao desserviço da vida cotidiana em sociedade.

\subsection{Sugestões para trabalhos futuros}

Desde o início este trabalho teve como propósito mostrar que a Matemática está presente em nosso cotidiano e que diariamente todos se deparam com situações que necessitam de conhecimento matemático para solução. A construção do Teodolito foi um meio utilizado para assimilar uma parte do conteúdo de Geometria presente no $8^{\circ}$ ano do Ensino Fundamental com o conhecimento prévio dos alunos. A proposta era utilizar materiais de baixo custo, que fossem facilmente adquiridos e preferencialmente recicláveis. Tendo essas características, possíveis erros em relação a precisão foram assumidos e através da teoria foram usados procedimentos para amenizá-los.

Como foi discutido, acredita-se que os valores calculados discrepantes da média foram devido a erros de leitura dos ângulos no Teodolito. A proposta para um trabalho futuro seria a aplicação dessa atividade aliada a uma técnica diferente, como, por exemplo, a utilização de um feixe de laser no lugar do canudo e do pedaço de arame presos ao copo descartável. Assim os movimentos secundários dos alunos seriam diminuídos e consequentemente a leitura dos dados se daria de forma mais precisa.

Como este trabalho foi realizado por alunos do $8^{\circ}$ ano, que ainda não possuem conhecimentos em Trigonometria, acredita-se que os resultados apresentados foram satisfatórios. Não obstante, foi usada a semelhança de triângulos para solucionar o problema e como consequência a construção dos triângulos também aumentam os erros nos cálculos, devido à pouca precisão no transferidor e régua escolar. 
Caso o trabalho fosse realizado com alunos do ensino médio, que já foram apresentados aos conceitos básicos de trigonometria, uma forma de amenizar a incerteza dos valores finais seria utilizando a tangente do ângulo obtido com o uso do Teodolito, como apresentado na equação 1.1 , e, neste caso, os erros devido à construção do triângulo usado na semelhança de triângulos seriam eliminados.

Há vários modos de minimizar erros cometidos durante a coleta de informações, no entanto, é importante verificar o nível de conhecimento prévio dos alunos e em que grau de escolaridade eles estão para poder trabalhar os conhecimentos matemáticos necessários para modelagem, execução e conclusão de uma situação problema. 


\section{REFERÊNCIAS BIBLIOGRÁFICAS}

AMORIM, José Alves de. Construção e utilização do Teodolito no Ensino Fundamental para medir grandes distâncias ou regiões inacessíveis. I CIPPEB Congresso Internacional de Práticas Pedagógicas da Educação Básica, v.1, dez. 2014.

ANASTACIO, Maria Queiroga Amoroso. Realidade: uma aproximação através da modelagem Matemática. Revista de Modelagem na Educação Matemática, v.1, n.1, 2010.

ANDRINI, Álvaro; VASCONCELLOS, Maria José. Praticando Matemática - volume 8. 3 ed. São Paulo. Do Brasil, 2012.

BASSANEZI, Rodney C. Ensino-aprendizagem com modelagem Matemática: uma nova estratégia. São Paulo: Contexto, 2002.

BORGES, Pedro Augusto Pereira. Modelos em diferentes linguagens sobre análise de custos e lucros. Revista de Modelagem na Educação Matemática, v.1, n.1, 2010.

BOYER, Carl Benjamin. História da Matemática. Tradução: Elza F. Gomide. São Paulo: Edgar Blucher, 1974.

CHAVES, Juliana de Oliveira. Geometria Espacial no Ensino Fundamental: Uma reflexão sobre as Propostas Metodológicas. Dissertação de Mestrado Universidade Federal de Viçosa, Viçosa, 2013.

GAZETTA, Marineusa. A Modelagem como Estratégia de Aprendizagem da Matemática em Cursos de Aperfeiçoamento de Professores. Universidade do Estado de São Paulo, Rio Claro, 1989. 
GRANATO, Marcus. Museu de Astronomia e Ciências Afins - MAST. 2010. Disponível em:

<http://www.mast.br/multimidia instrumentos/teodolito atualidade.html>.

Acesso em: 06 de janeiro de 2015.

GRANJA, Carlos Eduardo de Souza Campos; PASTORE, José Luiz. Atividades Experimentais de Matemática nos Anos Finais do Ensino Fundamental. 1 ed. São Paulo. Somos Mestres, 2012.

HIRONDINO. Inicio historia de Portugal. 2012. Disponível em:

<http://www.hirondino.com/historia-de-portugal/quadrante>. Acesso em: 25 de novembro de 2015.

ITZCOVICH, Horacio. Iniciação ao Estudo Didático da Geometria: Das Construções às Demonstrações. 1 ed. São Paulo. Anglo, 2012.

LAVANHA, João Baptista. Pessoas en Madrid. 2012. Disponível em:

<http://pessoasenmadrid.blogspot.com.br/2012/05/joao-baptista-lavanha.html>. Acesso em: 11 de dezembro de 2015.

MORI, Iracema; ONAGA, Dulce Satiko. Matemática: Ideias e Desafios - volume 9. 17 ed. São Paulo. Saraiva, 2012.

MUELANER, Jody. Make a simple Groma.. 2015. Disponível em:

<http://www.muelaner.com/measurement/make-a-simple-groma>. Acesso em: 12 de setembro de 2015.

PERRENOUD, Philippe, Dez Novas competências para ensinar. Porto Alegre: Artes Médicas, 2000.

SÃO PAULO (SP). Secretaria Municipal da Educação. Caderno de Apoio e aprendizagem: Matemática / Programa de Orientações Curriculares- volume 8. São Paulo. Fundação Padre Anchieta, 2010. 
. Orientações Curriculares

e Proposição de Expectativas de Aprendizagem para o Ensino Fundamental: Matemática. São Paulo. SME / DOT, 2007.

SILVA, Vantielen da Silva; KLUBER, Tiago Emanuel. Modelagem Matemática nos anos iniciais do Ensino Fundamental: uma investigação imperativa. Revista Eletrônica de Educação, v.6, n.2, nov.2012.

SOUZA, Josevalo Silva. Matemática profissional. 2012. Disponível em:

$<$ http://matematicaprofissional.blogspot.com.br/2012/05/conhecendo-um-pouco-dahistoria-dos.html>. Acesso em: 09 de agosto de 2015.

TAVARES, Marcelo. Estatística Aplicada à Administração. 1 ed. Florianópolis. UFSC, 2011.

VIECILI, Cláudia Regina Confortin. Modelagem Matemática: uma proposta para o ensino da Matemática. Dissertação de Mestrado - Pontifícia Universidade Católica do Rio Grande do Sul, Porto Alegre, 2006.

ZILKHA, Esther. Utilização do GeoGebra na Construção de Instrumentos Teodolito. Dissertação de Mestrado - Instituto Nacional de Matemática Pura e Aplicada, Rio de Janeiro, 2014. 